\title{
Measurements of biomarker levels in flounder (Platichthys flesus) and blue mussel (Mytilus trossulus) from the Gulf of Gdańsk (southern Baltic)
}

\author{
Justyna Kopecka $^{\text {a,* }}$, Kari K. Lehtonen ${ }^{\text {b }}$, Janina Baršiené ${ }^{\text {c }}$, Katja Broeg ${ }^{\text {d }}$, \\ Pekka J. Vuorinen ${ }^{\mathrm{e}}$, Jens Gercken ${ }^{\mathrm{f}}$, Janusz Pempkowiak ${ }^{\mathrm{a}, *}$ \\ ${ }^{a}$ Institute of Oceanology Polish Academy of Sciences, ul. Powstańców Warszawy 55, PL-81-712 Sopot, Poland \\ ${ }^{\mathrm{b}}$ Finnish Institute of Marine Research, P.O. Box 2, FI-00561 Helsinki, Finland \\ c Institute of Ecology of Vilnius University, Akademijos 2, LT-2600 Vilnius, Lithuania \\ d Alfred Wegener Institute for Polar and Marine Research, Am Handelshafen 12, D-27570 Bremerhaven, Germany

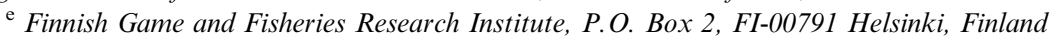 \\ ${ }^{\mathrm{f}}$ Institute of Applied Ecology, Lindenweg 2, D-18184 Neu Broderstorf, Germany
}

\begin{abstract}
In the framework of the EU funded BEEP project a set of biomarkers, gross morphometric indices and tissue concentrations of selected organic pollutants were measured in flounder (Platichthys flesus) and mussels (Mytilus trossulus) collected twice a year (April and October) from three sites in the inner Gulf of Gdańsk between autumn 2001 and spring 2003. In flounder, seasonal differences in most biomarkers were observed, but no correlations with tissue pollutant levels could be found. In mussels, highly variable levels in biomarker responses were seen, but no clear seasonal or spatial trends, directly related to tissue concentrations, could be established. The observed biomarkers distribution the study sites are probably mostly caused by interannual, seasonal and individual variability and, in case of flounder, possibly by exchange of stocks between the sampling sites.
\end{abstract}

(c) 2006 Elsevier Ltd. All rights reserved.

Keywords: Baltic Sea; Biomarkers; Gulf of Gdańsk; Flounder; Mussel; Organic pollutants

\section{Introduction}

The aquatic environment is affected by different types of chemicals toxic to biota that originate from both natural (e.g. heavy metals and various polycyclic aromatic hydrocarbons (PAHs)) and anthropogenic sources (e.g. PAHs, polychlorinated biphenyls (PCBs), pesticides and heavy metals). Many organic contaminants and heavy metals enter readily the food chain and tend to bioaccumulate, while some of them are rapidly metabolised (McCarthy and Shugart, 1990; Livingstone et al., 1992; Livingstone, 1993).

\footnotetext{
${ }^{*}$ Corresponding authors. Tel.: +48 5855172 81; fax: +48 585512130.

E-mail addresses: jkopecka@poczta.onet.pl (J. Kopecka), pempa@ iopan.gda.pl (J. Pempkowiak).
}

Traditionally, in order to monitor the effects of contaminants on biota analysis of tissue concentrations of selected compounds are carried out. A different approach is to measure the specific biological effects that different types of substances produce (Walker, 1995). Biomarkers are an integral part of this approach (McCarthy and Shugart, 1990; Peakall, 1992) and many of them are recommended tools for assessing the impacts of pollution on marine organisms (ICES WGBEC, 2004). Specifically, effects at the biochemical level are generally used as "early warning" signals for assessing the effects of contaminants on organisms (Haux and Förlin, 1988). This is due to the sensitivity, ease of application, low cost and specificity to pollution stress of many biomarkers (Livingstone et al., 1992; WHO, 1993).

Between 2001 and 2004, a pan-European EU funded research programme titled "Biological Effects of 
Environmental Pollution in Marine Coastal Ecosystems" (BEEP) was carried out. A part of the BEEP project comprised of biomonitoring activities in different parts of the Baltic Sea (Lehtonen and Schiedek, 2006). The Gulf of Gdańsk in the southern part of the Baltic was selected as one of the five Baltic Sea study sites. The area is under a marked influence of inflow from the large Vistula River and sewage discharge from the Gdańsk-Sopot-Gdynia urban agglomeration consisting of a population of over one million people. In regard to biomarkers in fish and bivalve species only a limited number of studies have so far been performed in this area (Draganik et al., 1996; Kopecka and Pempkowiak, 2002, 2003, 2004; Napierska and Podolska, 2003a,b, 2005; Kopecka et al., 2004).

A suite of biomarkers reflecting exposure to and effects of contaminants at different biological levels were selected for this study. In regard to detoxification of organic contaminants the activity of CYP1A1, measured commonly as ethoxyresorufin- $O$-deethylase (EROD) activity, belonging to Phase I (biotransformation) enzymes, and glutathione- $S$ transferase (GST) involved in Phase II (conjugation) enzymes (Sijm and Opperhuizen, 1989; Stegeman et al., 1992) were chosen. Induction of EROD activity indicates not only exposure to organic chemicals such as PAHs, PCBs and dioxins (Livingstone, 1993; Bucheli and Fent, 1995) but may also precede effects manifested at various levels of biological organisation (Whyte et al., 2000; van der Oost et al., 2003). GSTs catalyse the conjugation of the tripeptide glutathione (GSH) with xenobiotics (e.g. PAHs and PCBs) (Clark, 1989; Stegeman et al., 1992) and metals (Pellerin-Massicotte, 1994; Regoli and Principato, 1995). Catalase (CAT) is a hematin-containing enzyme that reduces hydrogen peroxide $\left(\mathrm{H}_{2} \mathrm{O}_{2}\right)$ to water and is widely used as a biomarker of oxidative stress (Winston and Di Giulio, 1991; Stegeman et al., 1992). Chemical analyses of fish bile have proved suitable to study the uptake of hydrocarbons and chlorinated organic compounds (Ariese et al., 1993). The levels of PAH metabolites in bile can be estimated as fluorescent aromatic compounds (FAC) (Ariese et al., 1993; Vuontisjärvi et al., 2004; Vuorinen et al., 2006). Inhibition of acetylcholinesterase (AChE) activity is commonly applied as a biomarker of exposure to organophosphorus and carbamate compounds used as active agents in many pesticides (Bocquené et al., 1990; Peakall, 1992; Escartin and Porte, 1997), but it responds also to other compounds including metals, detergents, hydrocarbons and algal toxins (Payne et al., 1996; Guilhermino et al., 1998; Lehtonen et al., 2003). Metallothioneins (MT) constitute a family of low-molecular weight, cysteine-rich proteins induced by a wide variety of metal ions (e.g. $\mathrm{Cd}, \mathrm{Cu}, \mathrm{Zn}, \mathrm{Hg}, \mathrm{Co}, \mathrm{Ni}$, $\mathrm{Bi}$ and $\mathrm{Ag}$ ) (Stegeman et al., 1992; Roesijadi, 1992; Viarengo et al., 1999, 2000). Vitellogenin (VTG) is a high-molecular weight lipophosphoprotein which, in vertebrates, is synthesised in the liver and regulated by $17 \beta$-estradiol (Melancon et al., 1992; Kleinkauf et al., 2004a,b,c). Plasma concentrations of VTG in male fish have been used as a sensitive biomarker of exposure to a variety of compounds that produce estrogenic effects, recently including also PCBs and PAHs (van der Oost et al., 2003). Lysosomes are a morphologically heterogeneous group of membrane-bound sub-cellular organelles (Mayer et al., 1992) that play a key role in the catabolism of cellular components, intracellular transport of macromolecules and in the uptake and sequestration of organic and inorganic pollutants and their metabolites (Köhler and Pluta, 1995). The frequency of micronuclei (MN) is among the most widely used methods to assess of cytogenetic damage. The MN test enables the evaluation of the influence of genotoxic compounds at low concentrations and the assessment of dose-response relationships of both DNA reactive genotoxins and nonDNA reactive aneugens (Baršienè et al., 2004). Gross morphometric indices including condition factor (CF), gonadosomatic index (GSI) and hepatosomatic index (HSI) are potentially indicative of toxicant effects, providing information on energy reserves and the ability of individuals to tolerate chemical pollution challenge or other kinds of environmental stress (Mayer et al., 1992; van der Oost et al., 2003).

The use of biomarkers in selected indicator species ("biomonitors") could be standardised to provide a database for future monitoring programmes (Goksøyr et al., 1996). Flounder (Platichthys flesus) is a widely distributed species in northern European coastal waters, including the Baltic Sea. This bottom-dwelling fish that prefers finegrained to sandy sediments is regarded as a good indicator of pollution effects (Goksøyr et al., 1996; Burgeot et al., 2001). The blue mussel (Mytilus spp.), a sedentary suspension-feeding species is a cosmopolitan, dominant member of coastal and estuarine communities and therefore extensively used as a sentinel or indicator species in environmental monitoring programmes (e.g. Widdows and Donkin, 1992). In the Gulf of Gdańsk the mussel populations consist mainly of Mytilus trossulus. The species above were selected as target organisms for this study.

Samples were obtained during four seasonal sampling campaigns between October 2001 and April 2003. By applying this sampling scheme the suitability of biomarkers in establishing the "health status" of selected sites in the Gulf of Gdańsk was assessed using the flounder and mussel as biomonitoring organisms. To assess the level of contamination in the study area, concentrations of PCBs, DDTs, HCB, HCH and polybrominated diethyl ethers (PBDEs) were analysed from selected flounder tissue samples.

\section{Materials and methods}

\subsection{Study area and sampling}

The bathymetry and bottom sediments of the Gulf of Gdańsk are variable. The coastal areas are sandy while the open-sea part is situated at the edge of a deep sedimentary basin. The Inner Puck Bay forms a unique separate shallow basin in the western part of the gulf (Fig. 1). 
The samples were collected following the general sampling strategy and procedures of the BEEP project Baltic Sea component. Flounder and mussels were collected from three sites along a suspected pollution gradient based on previous information on local contaminant levels (Pazdro, 2004) (Fig. 1): (1) Mechelinki, regarded as the most polluted of the three sites, located close to the sewage outflow from the Gdynia Waste Water Treatment Plant; (2) Sobieszewo, close to the mouth of the Vistula River; (3) Sopot, a recreational and tourist area. Bi-annual samplings were performed in October (2001 and 2002) and April (2002 and 2003).

Water depth, temperature and salinity at the sampling sites were measured during all sampling campaigns (Table 1). Mussels (shell length range $35 \pm 5 \mathrm{~mm}$ ) were collected aboard $\mathrm{r} / \mathrm{v}$ "Oceania" using a drag net towed at the speed of 2.5-3 knots for 15-20 min. The mussels were kept in aerated seawater prior to dissection of target tissues aboard the vessel within $2-3 \mathrm{~h}$ from collection. Tissue samples were placed in cryovials, snap-frozen in liquid nitrogen and stored in an ultrafreezer $\left(-80^{\circ} \mathrm{C}\right)$. Flounder (size range $24-30 \mathrm{~cm}$ ) were collected by local fishermen using gillnets. Within $2 \mathrm{~h}$ the catch was transferred to 301 tanks filled with aerated seawater and transported to the laboratory, where the individuals were dissected during the same day. Total length and weight as well as liver, gonad and spleen weights were determined for each individual. The dissected tissues were frozen in cryovials in liquid nitrogen and stored at $-80^{\circ} \mathrm{C}$ (unless stated otherwise; see below) until the biomarker analyses. Samples for the different analyses were distributed among the BEEP Baltic Sea partner laboratories according to their analytical expertise. In regard to flounder the assessment of biomarker responses focuses on data obtained from females.

\subsection{Biomarker measurements}

AChE. The method of Ellman et al. (1961) modified for microplate readers by Bocquené and Galgani (1998) was used for the measurement of AChE activity in the muscle (flounder) or gill (mussels) tissue. Details of the method are described in Kopecka et al. (2004).

EROD. The procedure of Burke and Mayer (1974) modified for microplate readers using the S9 fraction (Galgani and Payne, 1991; Stagg and McIntosh, 1998) was applied for the determination of EROD activity in the liver tissue of flounder.

GST and CAT. For the measurement of GST activity (flounder: liver, mussels: digestive gland) the procedure of Habig et al. (1974) was followed. The method described by Claiborne (1985) was used for the determination of CAT activity (flounder: liver, mussels: gills). The analyses of GST activity was performed as a microplate reader assay (GENios, TECAN). CAT activity was measured using a spectrophotometer $\left(\mathrm{DU}^{\circledR}-62\right.$, Beckman).

LMS. Lysosomal membrane stability was assessed histochemically from liver (flounder) and digestive gland (mussels) tissue sections according to a standard operation procedure described in detail by Köhler et al. (2002).

$M T$. The analysis of MT was performed according to the method of Viarengo et al. (1997), using liver (flounder) or digestive gland (mussels) tissue. In flounder, the analyses were mostly performed on individual fish but occasionally (15\% of cases) tissues from two individuals had to be pooled. In mussels, the analyses were always carried out using 5-8 pooled individuals. For more methodological details, see Leiniö and Lehtonen (2005).

$M N$. The analysis of $\mathrm{MN}$ in the hematocytes of flounder and the gill cells of mussels was performed according to Baršiene et al. (2004, 2006a,b).

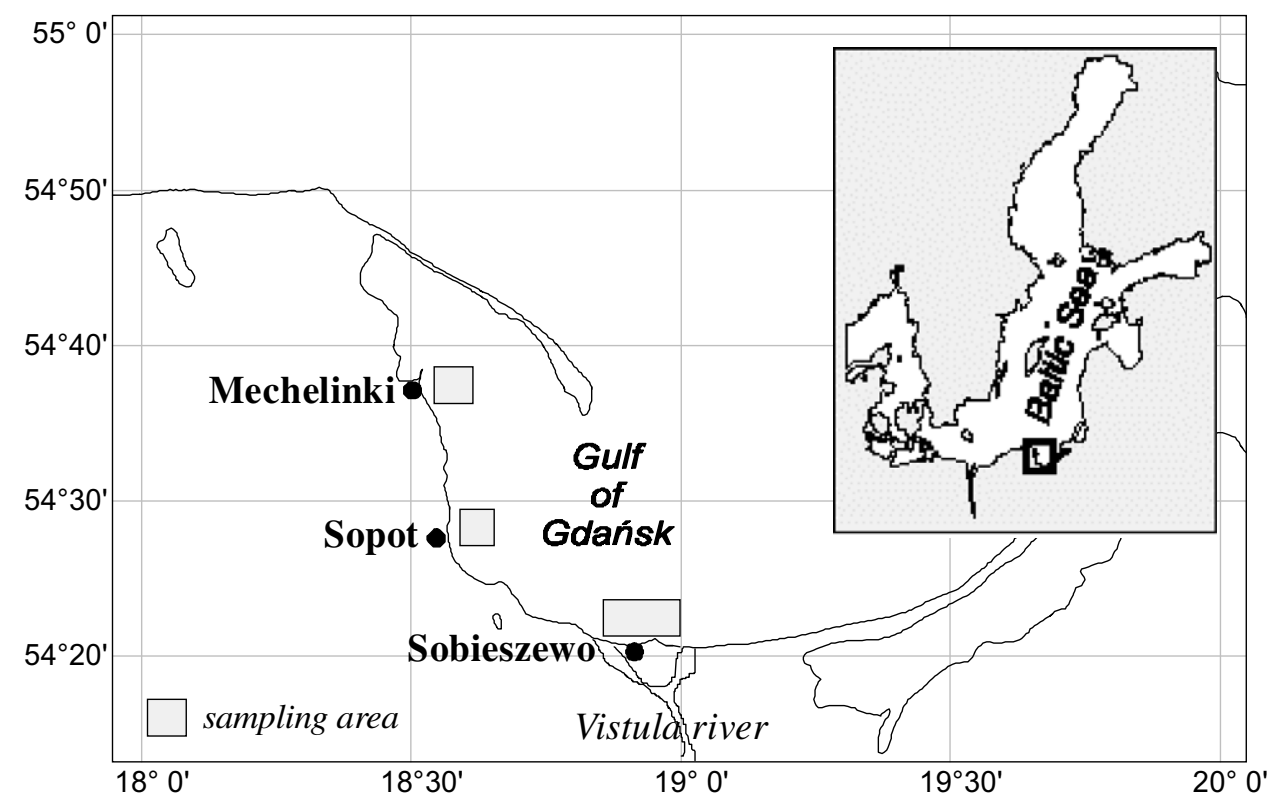

Fig. 1. Map of the BEEP sampling sites in the Gulf of Gdańsk. 
Table 1

Background information on the sampling stations in the Gulf of Gdańsk

\begin{tabular}{|c|c|c|c|c|c|c|c|}
\hline \multirow[t]{2}{*}{ Campaign } & \multirow[t]{2}{*}{ Sampling date } & \multirow[t]{2}{*}{ Station } & \multicolumn{2}{|c|}{ Coordinates } & \multirow[t]{2}{*}{ Depth (m) } & \multirow[t]{2}{*}{ Temperature $\left({ }^{\circ} \mathrm{C}\right)$} & \multirow[t]{2}{*}{ Salinity (PSU) } \\
\hline & & & Latitude & Longitude & & & \\
\hline \multirow[t]{3}{*}{ Autumn 2001} & $19.10^{\mathrm{a}} / 07.10^{\mathrm{b}}$ & Mechelinki & $54^{\circ} 37.4 \mathrm{~N}$ & $18^{\circ} 36.6 \mathrm{E}$ & 20 & 14.8 & 6.84 \\
\hline & $18.10^{\mathrm{a}} / 06.11^{\mathrm{b}}$ & Sobieszewo & $54^{\circ} 24.8 \mathrm{~N}$ & $18^{\circ} 52.8 \mathrm{E}$ & 28 & 10.2 & 7.24 \\
\hline & $26.10^{\mathrm{a}} / 06.10^{\mathrm{b}}$ & Sopot & $54^{\circ} 28.3 \mathrm{~N}$ & $18^{\circ} 40.3 \mathrm{E}$ & $10-25$ & 14.1 & 6.81 \\
\hline \multirow[t]{3}{*}{ Spring 2002} & $25.04^{\mathrm{a}} / 21.03^{\mathrm{b}}$ & Mechelini & $54^{\circ} 37.9 \mathrm{~N}$ & $18^{\circ} 34.5 \mathrm{E}$ & 16 & 3.2 & 7.07 \\
\hline & $24.04^{\mathrm{a}} / 23.03^{\mathrm{b}}$ & Sobieszewo & $54^{\circ} 24.6 \mathrm{~N}$ & $18^{\circ} 53.4 \mathrm{E}$ & 29 & 3.3 & 7.01 \\
\hline & $19.04^{\mathrm{a}} / 24.03^{\mathrm{b}}$ & Sopot & $54^{\circ} 29.1 \mathrm{~N}$ & $18^{\circ} 39.7 \mathrm{E}$ & 17 & 3.2 & 7.06 \\
\hline \multirow[t]{3}{*}{ Autumn 2002} & $16.10^{\mathrm{a}} / 14.11^{\mathrm{b}}$ & Mechelinki & $54^{\circ} 36.2 \mathrm{~N}$ & $18^{\circ} 33.5 \mathrm{E}$ & 11 & 9.4 & nd \\
\hline & $28.10^{\mathrm{a}} / 15.11^{\mathrm{b}}$ & Sobieszewo & $54^{\circ} 24.3 \mathrm{~N}$ & $18^{\circ} 52.5 \mathrm{E}$ & 22 & 8.5 & nd \\
\hline & $25.10^{\mathrm{a}} / 23.10^{\mathrm{b}}$ & Sopot & $54^{\circ} 28.9 \mathrm{~N}$ & $18^{\circ} 39.9 \mathrm{E}$ & 16 & nd & nd \\
\hline \multirow[t]{3}{*}{ Spring 2003} & $22.04^{\mathrm{a}} / 16.04^{\mathrm{b}}$ & Mechelinki & $54^{\circ} 36.5 \mathrm{~N}$ & $18^{\circ} 33.3 \mathrm{E}$ & 16 & 7.0 & nd \\
\hline & $24.04^{\mathrm{a}} / 14.04^{\mathrm{b}}$ & Sobieszewo & $54^{\circ} 24.9 \mathrm{~N}$ & $18^{\circ} 53.4 \mathrm{E}$ & 25 & nd & nd \\
\hline & $06.05^{\mathrm{a}} / 16.04^{\mathrm{b}}$ & Sopot & $54^{\circ} 28.6 \mathrm{~N}$ & $18^{\circ} 40.5 \mathrm{E}$ & 14 & nd & nd \\
\hline
\end{tabular}

nd $=$ No data available

a Flounder sampling.

b Mussel sampling.

$V T G$. Concentrations of VTG in the plasma of flounder were quantified by means of an indirect competitive ELISA using a polyclonal rabbit antibody against perch (Perca fluviatilis) kindly provided by Prof. Lars Förlin (Gothenburg University). A detailed method description is found in Gercken et al. (2006).

PAH metabolites. Fluorescent aromatic compounds (FACs) were measured in the bile of flounder using the fixed wavelength fluorescence method (FF) according to Vuontisjärvi et al. (2004) and Vuorinen et al. (2006).

Protein. Protein in the S9 fraction used for calculating the specific activity of AChE, EROD, GST and CAT was measured by the method of Bradford (1976) with BSA (bovine serum albumin, Sigma) as the standard (see also Kopecka et al., 2004).

\subsection{Gross morphometric indices}

Gross morphometric indices were calculated for each individual flounder according to the following formulas:

condition factor $(\mathrm{CF}):\left(W_{\mathrm{T}} / L^{3}\right) \times 100$;

hepatosomatic index $(\mathrm{HSI}):\left(W_{\mathrm{H}} / W_{\mathrm{T}}\right) \times 100$;

gonadosomatic index $(\mathrm{GSI}):\left(W_{\mathrm{G}} / W_{\mathrm{T}}\right) \times 100$,

where $W_{\mathrm{T}}=$ total wet weight $(\mathrm{g}), L=$ total length $(\mathrm{cm})$, $W_{\mathrm{H}}=$ liver weight $(\mathrm{g})$ and $W_{\mathrm{G}}=$ gonad weight $(\mathrm{g})$.

\subsection{Analysis of organic contaminants in flounder muscle tissue}

Flounder muscle tissue samples were analysed for the following organic contaminants: dichlorodiphenyltrichloroethane (DDT) and its metabolites, polychlorinated biphenyls (PCB), hexachlorocyclohexanes $(\mathrm{HCH})$, hexachlorobenzene (HCB), and polybrominated diphenyl ethers (PBDE). Analyses were performed on composite samples of 2-3 individuals selected according to station, sampling occasion and observed biomarker response established as the individuals having the highest and the lowest GST activities. Details of the methodology are given in Zebühr (1992) and Koslowski et al. (1994).

\subsection{Statistical treatment of data}

Relationships between the different biomarker responses in female and male flounder and seasonal differences (spring and autumn) were evaluated by Student's $t$-test (significance level at $p<0.05$ ), except for $\mathrm{MN}$ for which the non-parametric Mann-Whitney $U$-test was applied. Seasonal and geographical differences in biomarker responses in flounder and mussels were assessed by the ANOVA rank Kruskal-Wallis non-parametric test designed for data sets with $n<30(p<0.05)$. Linear Pearson correlations were used to examine dependencies between the biomarkers $(p<0.05)$. Principal component analysis (PCA) was performed on a flounder data set consisting of four biomarkers (AChE, EROD, GST and CAT) and the three gross morphometric indices (CF, HSI and GSI) measured in 20 specimens collected at each of the three sites during all four sampling campaigns (a total of 1680 data points). All statistical analyses were performed using STATISTICA ${ }^{\circledR} 5.0$ software package.

\section{Results}

\subsection{Flounder}

\subsubsection{Biomarker ranges, and geographical, seasonal and gender differences}

AChE. Mean activity of AChE in females ranged between 68.8 (Mechelinki, October 2002) and 187.1 nmol min ${ }^{-1} \mathrm{mg}_{\text {protein }}{ }^{-1}$ (Mechelinki, October 2001) 
(Fig. 2). Statistically significant differences in AChE activity between the sampling stations could be observed only in October 2001. No differences were found between the sampling seasons (two autumns and two springs) $(p>0.05)$. Among all sampling campaigns significant differences were observed in Mechelinki and Sobieszewo. No significant differences between females and males could be found $(p=0.3076)$.

EROD. EROD activity was 3-20 times higher in spring compared to autumn, depending on site and year (Fig. 2). In autumn, mean EROD activity in females ranged between 102.4 (Sopot, October 2001) and

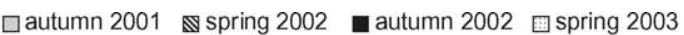
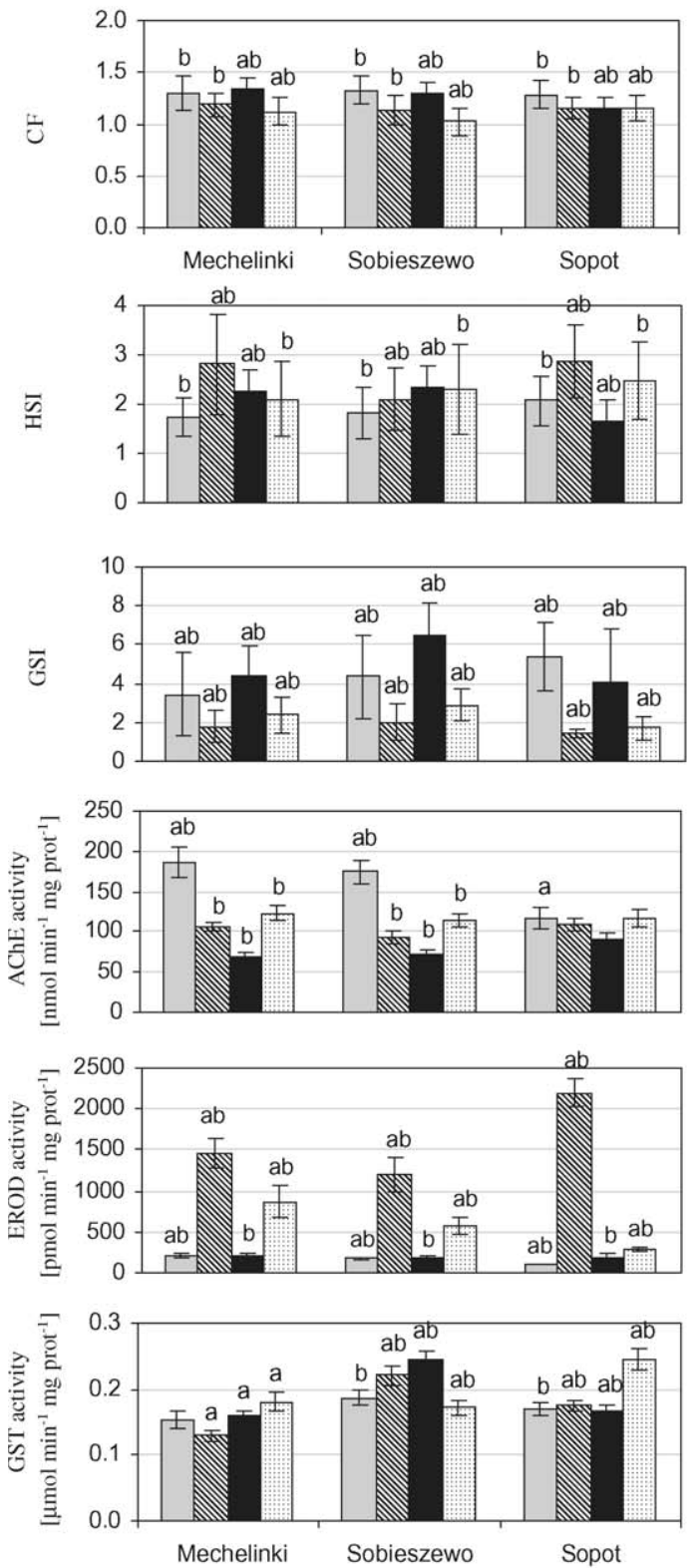

口autumn $2001 \mathbb{8}$ spring 2002 a autumn 2002 @spring 2003
$212.3 \mathrm{pmol} \mathrm{min}^{-1} \mathrm{mg}$ protein ${ }^{-1} \quad$ (Mechelinki, October 2001) while in spring the range was from 1197.8 (Sobieszewo, April 2002) to $2198.0 \mathrm{pmol} \mathrm{min}^{-1} \mathrm{mg}$ protein $^{-1}$ (Sopot, April 2002). Significant differences between the study sites were recorded in three out of four sampling campaigns. Significant seasonal variability was observed also between autumn and spring seasons at each sampling site $(p<0.001)$ and between all sampling campaigns at each station. In males the EROD activity was generally higher than in females, being significantly higher in males collected during sampling campaigns of October 2002 and April $2003(p<0.001)$.

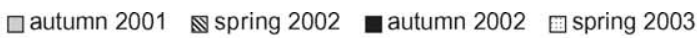
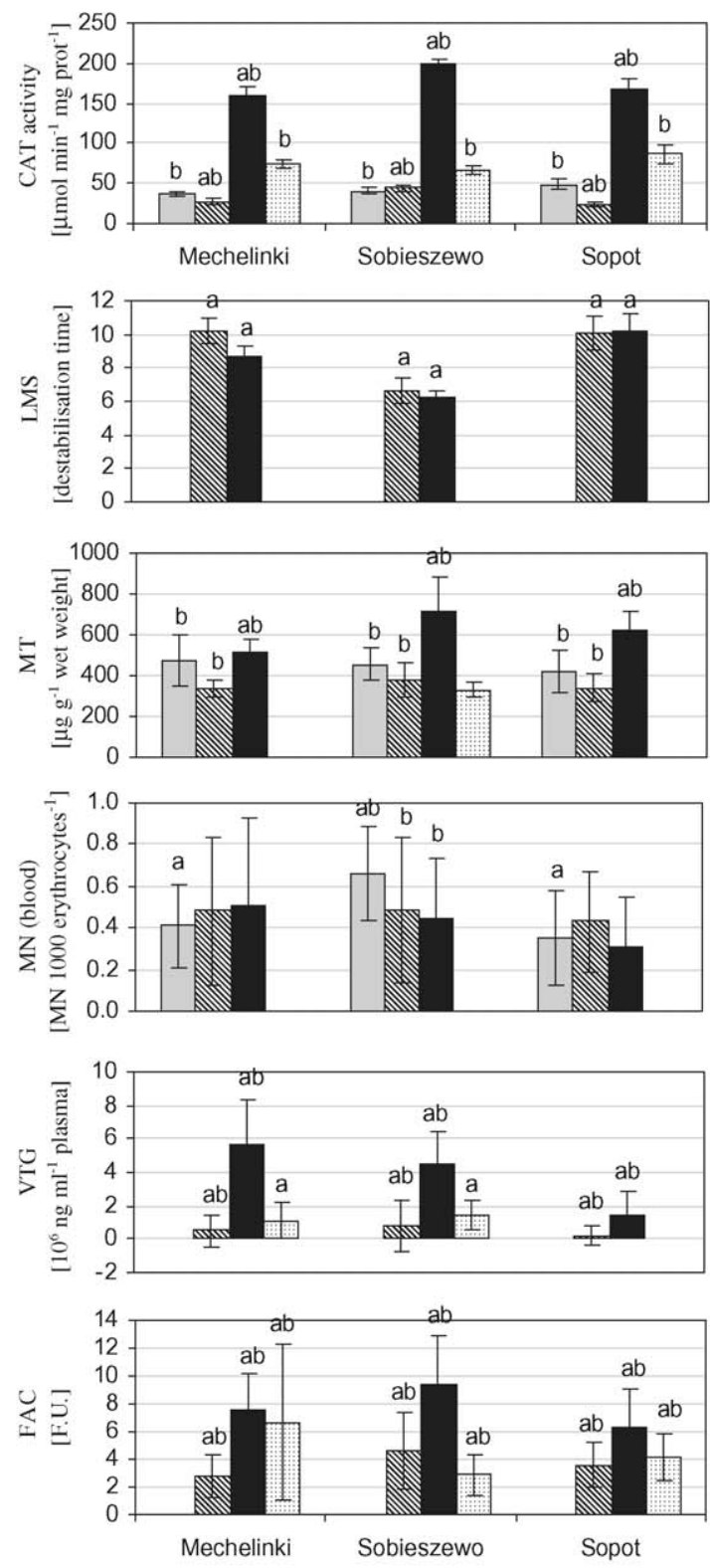

口autumn 2001 \$spring 2002 a autumn 2002 ospring 2003

Fig. 2. Platichthys flesus. Mean values $( \pm \mathrm{SD})$ of the different biomarkers measured in female flounder at the three study stations in the Gulf of Gdańsk during 2001-03. Statistically significant differences (Kruskal-Wallis ANOVA, $p<0.05$ at least) between the sampling sites are indicated by "a" and seasonal differences within each site by "b". 
GST. Mean GST activity in females ranged between 0.130 (Mechelinki, April 2002) and $0.245 \mu \mathrm{mol}$ $\min ^{-1} \mathrm{mg} \mathrm{protein}^{-1}$ (Sopot, April 2003) (Fig. 2). Significant geographical differences were observed except in samples collected in October 2001. Seasonal variability between autumn and spring samples was significant at station Sopot $(p<0.01)$ and between all the sampling campaigns at stations Sobieszewo and Sopot. GST activity in males was always significantly higher compared to females at all sampling sites during all campaigns $(p<0.001)$.

$C A T$. Mean activity of CAT in females ranged from 24.3 (Sopot, April 2002) to $199.5 \mu \mathrm{mol} \mathrm{min}^{-1} \mathrm{mg} \mathrm{protein}^{-1}$ (Sobieszewo, October 2002) (Fig. 2). The highest activities were measured in October 2002 at all sampling sites. Significant differences between the sites could be observed in April 2002 and October 2002. Seasonal variability was significant between the autumn and spring at each sampling site $(p<0.001)$ and between all sampling campaigns at each station. CAT activity was always significantly higher in males compared to females $(p<0.001)$.

$L M S$. LMS in female flounder was measured only in spring and autumn 2002. Mean LMS ranged from 6.20 (Sobieszewo, April 2002) to $10.28 \mathrm{~min}$ (destabilisation time) (Sopot, October 2002) (Fig. 2). Significant differences between the study sites could be observed both in autumn and spring. No significant seasonal differences were found $(p>0.05)$.

$M T$. Average concentration of MT in pooled liver samples from females ranged from 331.5 (Sobieszewo, April

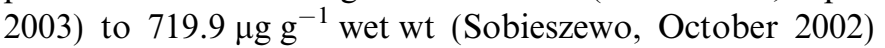
(Fig. 2). Statistically significant differences between the sampling sites were observed only in autumn 2002. Significant differences in MT levels between the autumn and spring samplings were found at each sampling site $(p<0.001)$.

$M N$. Mean $\mathrm{MN}$ frequency in females ranged from 0.31 to $0.66 \mathrm{MN} 1000$ erythrocytes $^{-1}$ (Fig. 2). The lowest MN levels $\left(0.31-0.43 \mathrm{MN} 1000\right.$ erythrocytes $\left.^{-1}\right)$ were detected in individuals from station Sopot while higher responses were observed at stations Sobieszewo $(0.44-0.66 \mathrm{MN}$ 1000 erythrocytes $\left.^{-1}\right)$ and Mechelinki (0.41-0.65 MN 1000 erythrocytes $^{-1}$ ). At station Mechelinki an apparent increase in $\mathrm{MN}$ frequency during the study period could be observed but the trend was not statistically significant. The MN values in flounder collected from Sobieszewo in October 2001 differed significantly from those recorded at stations Sopot and Mechelinki in October 2001 and 2002 (from $p=0.0116$ to $p<0.0001$ ). A significantly elevated level of genotoxicity was observed in individuals caught at station Mechelinki (April 2003) compared to those inhabiting the Sopot locality.

$V T G$. Mean concentrations of VTG in the blood plasma of females ranged from $0.2 \times 10^{6}$ (Sopot, April 2002) to $5.7 \times 10^{6} \mathrm{ng} \mathrm{ml}^{-1}$ (Mechelinki, October 2002) (Fig. 2). The levels differed intensely between the sampling sites according to season. VTG concentrations in females in Sopot were markedly lower than in Mechelinki and Sob- ieszewo both in October 2002 and April 2003. The levels showed significant seasonal variability $(p<0.001)$ and also between all sampling campaigns at each sampling site. In males the VTG levels were several orders of magnitude lower than in females, ranging from 216 (Mechelinki, April 2002) to $5291 \mathrm{ng} \mathrm{ml}^{-1}$ (Sopot, October 2002).

PAH metabolites in bile. Mean concentration of FACs in the bile of females ranged from 3 to 9 F.U. (fluorescence units) (Fig. 2). The levels were highest at all stations in October 2002 compared to both spring campaigns. Statistically significant differences were observed between the sampling sites during each campaign and between the sampling seasons in Mechelinki $(p<0.05)$, Sobieszewo $(p<0.01)$, Sopot $(p<0.001)$ and between all sampling campaigns.

\subsubsection{Morphometric condition indices}

$C F$. In females, the mean $\mathrm{CF}$ ranged from 1.02 (Sobieszewo, April 2003) to 1.34 (Mechelinki, October 2002) (Fig. 2). Significant differences between the stations occurred in autumn 2002 and spring 2003 between the different sampling seasons (two autumns and two springs) in Mechelinki and Sobieszewo $(p<0.001)$ and in Sopot $(p<0.05)$, and between all sampling campaigns at all and each sampling station. The CF did not differ significantly between the sexes $(p=0.1897)$.

HSI. In females, the mean HSI ranged between 1.66 (Sopot, October 2002) and 2.87 (Sopot, April 2002) (Fig. 2). Significant geographical differences in HSI could be observed in April 2002 and October 2002. Variability between the autumn and spring samples was significant at all stations $(p<0.01)$ except for Sobieszewo $(p>0.05)$. In males the HSI was significantly lower compared to females at all sampling sites during all campaigns $(p<0.001)$.

GSI. In females, the mean GSI ranged between 1.46 (Sopot, April 2002) and 6.43 (Sobieszewo, October 2002) (Fig. 2). Statistically significant differences between stations during each campaign, between seasons $(p<0.01)$ and among all sampling campaigns at all and each sampling stations were observed. In males the GSI was significantly lower than in females at all sites and during all campaigns $(p<0.001)$.

\subsubsection{PCA on selected biomarkers and gross morphometric indices}

Similar to the results obtained using ANOVA, seasonal (Fig. 4a) and year-to-year variability (Fig. 4b) could be seen in PCA performed on selected biomarkers and gross morphometric indices. Differences between the sampling sites were also observed (Fig. 4c, Table 2). The separation of station Sopot in autumn 2001 and spring 2003 was mainly caused by variation in the stage of gonad maturity, indicated by differing GSI. In spring 2002, station Sobieszewo was separated from the other two by the activity of GST and CAT; higher levels of PCBs and DDTs in muscle tissue were also recorded in specimens from Sobieszewo during this sampling campaign (Fig. 5). 


\subsubsection{Tissue levels of contaminants}

In October 2001, the levels of $\sum$ PCB and $\sum D D T$ in the muscle tissue of flounder were relatively similar at all the study stations (145-165 and 348-492 $\mathrm{ng} \mathrm{g}^{-1}$ lipid wt, respectively) (Fig. 5). In April 2002, concentrations of $\sum$ PCB were elevated and markedly higher in specimens from Sobieszewo (235 $\mathrm{ng} \mathrm{g}^{-1}$ lipid wt) compared to Sopot and Mechelinki where no change could be seen compared autumn 2001 (155 and $157 \mathrm{ng} \mathrm{g}^{-1}$ lipid wt, respectively). At the same time, markedly higher $\sum$ DDT concentrations were also observed in Sobieszewo $\left(875 \mathrm{ng} \mathrm{g}^{-1}\right.$ lipid wt) compared to Mechelinki (351 $\mathrm{ng} \mathrm{g}^{-1}$ lipid wt) and Sopot (507 $\mathrm{ng} \mathrm{g}^{-1}$ lipid wt). Tissue levels of $\mathrm{HCH}$ did not show any spatial or temporal variability $\left(17.8-20.8 \mathrm{ng} \mathrm{g}^{-1} \mathrm{li}\right.$ pid wt). HCB levels were stable in April 2002 (17.9$20.8 \mathrm{ng} \mathrm{g}^{-1}$ lipid wt) but had been up to 2-3 times higher in the previous autumn 2001 at Sobieszewo $\left(38.3 \mathrm{ng} \mathrm{g}^{-1} \mathrm{li}\right.$ pid wt) and Sopot (46.1 $\mathrm{ng} \mathrm{g}^{-1}$ lipid wt).

In October 2001 the levels of PBDE were twice higher at station Sopot (11.3 $\mathrm{ng} \mathrm{g}^{-1}$ lipid wt) compared to the two other sites (5.0-5.8 $\mathrm{ng} \mathrm{g}^{-1}$ lipid wt), but in April 2002 a quite opposite pattern could be seen at stations Sobieszewo and Mechelinki with 3-4 times higher levels to those measured in autumn (17.2 and $20.8 \mathrm{ng} \mathrm{g}^{-1}$ lipid wt, respectively) but no change in specimens collected from Sopot (12.2 $\mathrm{ng} \mathrm{g}^{-1}$ lipid wt).

Correlations between biomarker responses and tissue contaminant concentrations were analysed separately for the spring and autumn campaigns (Table 3). The most interesting positive correlations were observed between total organic contaminant loads ( $\sum$ POP) and CAT activity in October $2001(r=0.90)$, and with FAC $(r=0.56)$ and GSI ( $r=0.68)$ in April 2001. Also, negative correlations were observed between total contaminant levels and AChE activity (indicating inhibition) in October $2001(r=-0.72)$ and CF $(r=-0.56)$ in April 2002. Since $\sum$ PCB and $\sum$ DDT formed the major bulk of $\sum$ POP correlations with the respective groups were generally recorded (e.g. with CAT in autumn 2001 and GSI in spring 2002). Detoxification enzymes EROD and GST showed positive correlations only with $\mathrm{HCB}$ and $\sum \mathrm{HCH}$, respectively, in April 2002. The levels of VTG in females correlated with $\sum$ PCB $(r=0.67)$ and $\sum \operatorname{PBDE}(r=0.63)$ in April 2002. However, some biomarkers showed a negative correlation with tissue contaminant levels, most notably EROD with $\sum \mathrm{HCH}$ in autumn 2001 and GST with $\sum$ PCB in spring 2002.

\subsection{Mussels}

\subsubsection{Biomarker ranges, and geographical and seasonal differences}

$A C h E$. Mean AChE activity in mussels ranged from 15.1 (Mechelinki, October 2001) to $38.1 \mathrm{nmol} \mathrm{min}^{-1} \mathrm{mg}$ protein $^{-1}$ (Sopot, October 2001) (Fig. 3). Between-site variability was statistically significant only in October 2001 but almost significant also in spring $2002(p=0.066)$. No marked differences between the sampling campaigns could

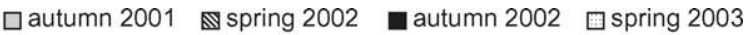
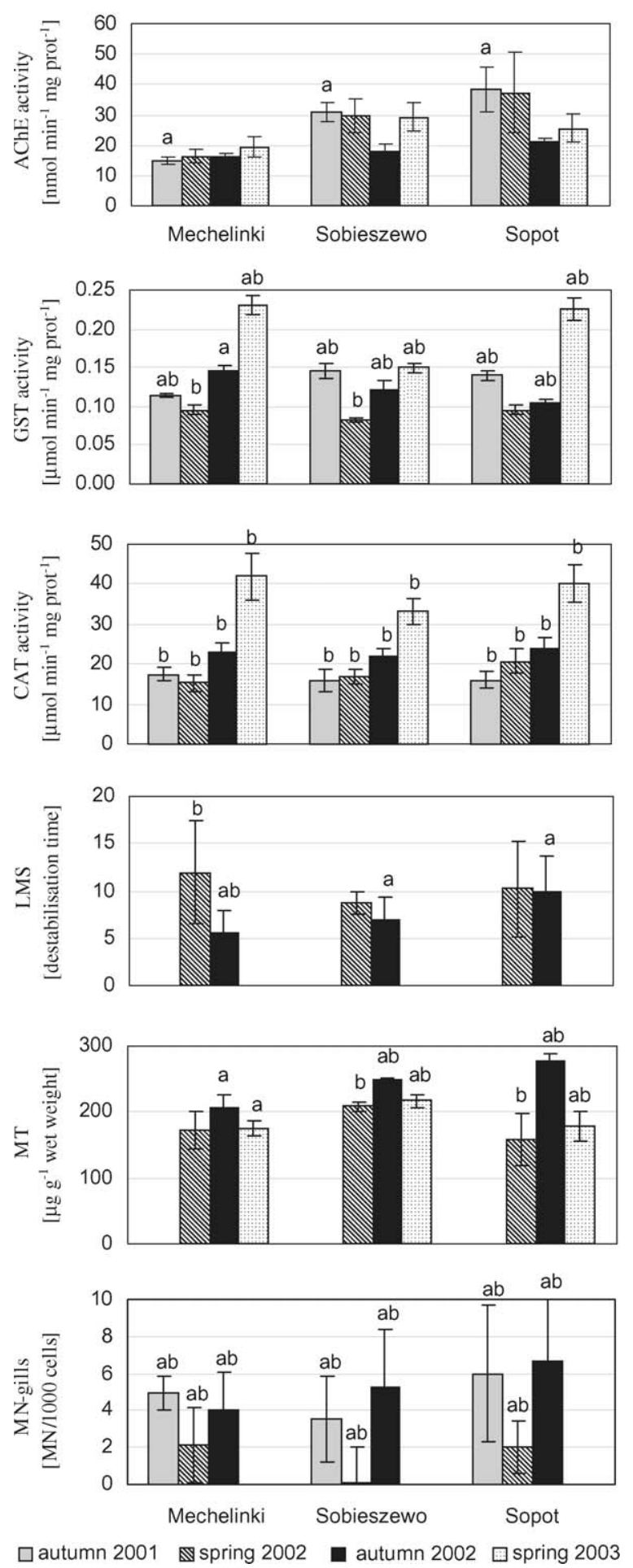

Fig. 3. Mytilus trossulus. Mean values $( \pm \mathrm{SD})$ of the different biomarkers measured in mussels at the three study stations in the Gulf of Gdańsk during 2001-03. Statistically significant differences (Kruskal-Wallis ANOVA, $p<0.05$ at least) between the sampling sites are indicated by "a" and seasonal differences within each site by "b".

be observed when the stations where either pooled or treated separately.

GST. Mean GST activity in mussels ranged from 0.082

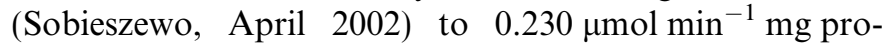



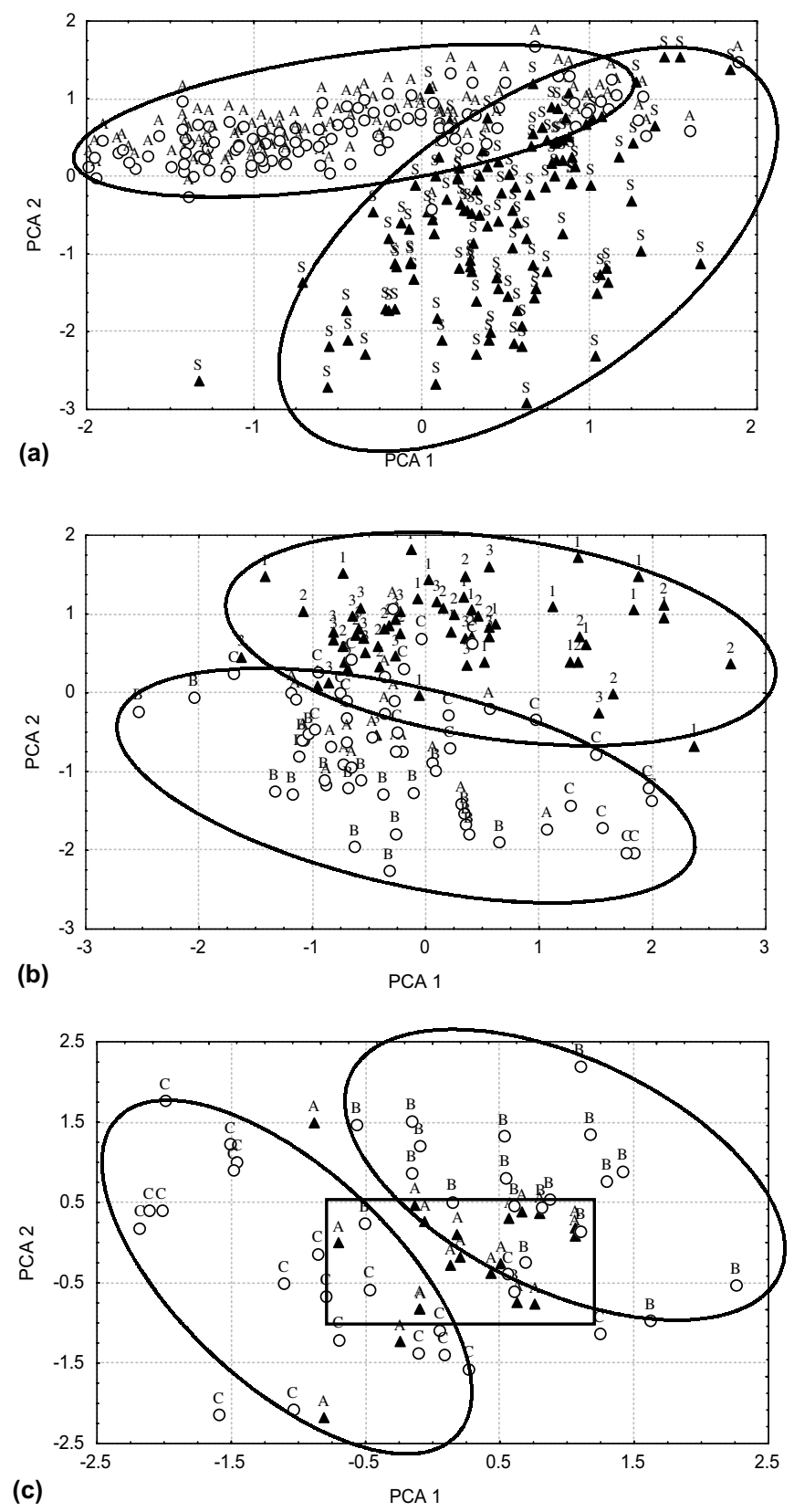

Fig. 4. Platichthys flesus. Selected PCA graphs showing (a) differences between the sampling sites during all sampling campaigns (A - autumns (October 2001 and 2002); S - springs (April 2002 and 2003)), (b) interannual variability (autumn 2001 and 2002) between the sampling sites (autumn 2001: 1 - Mechelinki, 2 - Sobieszewo, 3 - Sopot; autumn 2002: A - Mechelinki, B - Sobieszewo, C - Sopot), and (c) differences between the three sampling sites in autumn 2002 (A - Mechelinki, B - Sobieszewo, C Sopot). tein $^{-1}$ (Mechelinki, April 2003) (Fig. 3). Significant differences between the sampling sites were observed in all cases except for spring 2002. Seasonal variability in GST activity was marked both in pooled or separately treated stations.

CAT. Mean CAT activity ranged from 15.2 (Mechelinki, April 2002) to $41.9 \mu \mathrm{mol} \mathrm{min}^{-1} \mathrm{mg}$ protein ${ }^{-1}$ (Sobieszewo, April 2003) (Fig. 3). In April 2003 the activities were high at all sites in general. Mean CAT activities measured in spring (April 2002 and 2003) were significantly higher than those recorded in autumn (October 2001 and 2002; $p=0.0045$ ). No between-site differences could be observed while seasonal variability was great within all sampling sites.

MT. Mean levels of MT ranged from 158.2 (Sobieszewo, April 2002) to $275.8 \mu \mathrm{g} \mathrm{g}^{-1}$ wet wt (digestive gland) (Sobieszewo, October 2002) (Fig. 3). Significant between-site variability in MT levels was recorded in all cases except for spring 2002 and also seasonal differences occurred between all sites and at each study site, except for Mechelinki.

$M N$. In autumn 2001 and 2002 the mean levels of MN reached 6.0 MN 1000 cells $^{-1}$ in mussels from stations Sopot and Mechelinki (Fig. 3). In samples collected in early spring 2002 (March 21-24) the mean frequency of MN was significantly lower than in those obtained in autumn (October-November 2001) and practically identical at all stations. Geographical differences in $\mathrm{MN}$ levels were observed during all sampling campaigns except for spring 2002 and also seasonal variability occurred at each site.

$L M S$. Mean LMS showed a maximum of 11.70 and a minimum of 5.45 min (destabilisation time) in April and October 2002, respectively (Fig. 3). At station Mechelinki a significant difference in LMS could be noted between the two seasonal campaigns. Statistically significant differences between the sampling sites were recorded only in autumn 2002 while seasonal variability was significant when all stations were pooled and at station Mechelinki alone.

\section{Discussion}

\subsection{Factors influencing biomarker levels in flounder in the Gulf of Gdańsk}

Various biotic and abiotic factors are well known to affect biomarker responses. In the Baltic Sea seasonality in various environmental factors is more distinct than in

Table 2

Platichthys flesus; principal component analysis (PCA) on data of selected biomarkers and morphometric condition indices (see text)

\begin{tabular}{|c|c|c|c|c|c|c|}
\hline \multirow[t]{2}{*}{ Campaign assessed } & \multicolumn{3}{|c|}{$\begin{array}{l}\text { Explained variability } \\
(\%)\end{array}$} & \multicolumn{3}{|l|}{$\mathrm{PC}$ assignment } \\
\hline & $\mathrm{PC} 1$ & $\mathrm{PC} 2$ & PC3 & $\mathrm{PC} 1$ & $\mathrm{PC} 2$ & PC3 \\
\hline Autumn 2001 & 39.3 & 17.0 & 15.0 & Station Sopot separated by GSI & CAT & EROD \\
\hline Spring 2002 & 26.2 & 21.0 & 19.3 & Station Sobieszewo separated by GST and CAT & $\mathrm{CF}, \mathrm{HSI}$ & GSI \\
\hline Autumn 2002 & 38.6 & 22.1 & - & Stations Mechelinki, Sobieszewo and Sopot separated by GSI & EROD,GST,CAT & \\
\hline Spring 2003 & 45.0 & 17.5 & - & Station Sopot separated by CF, GSI, HSI and GST & AChE,EROD & \\
\hline
\end{tabular}




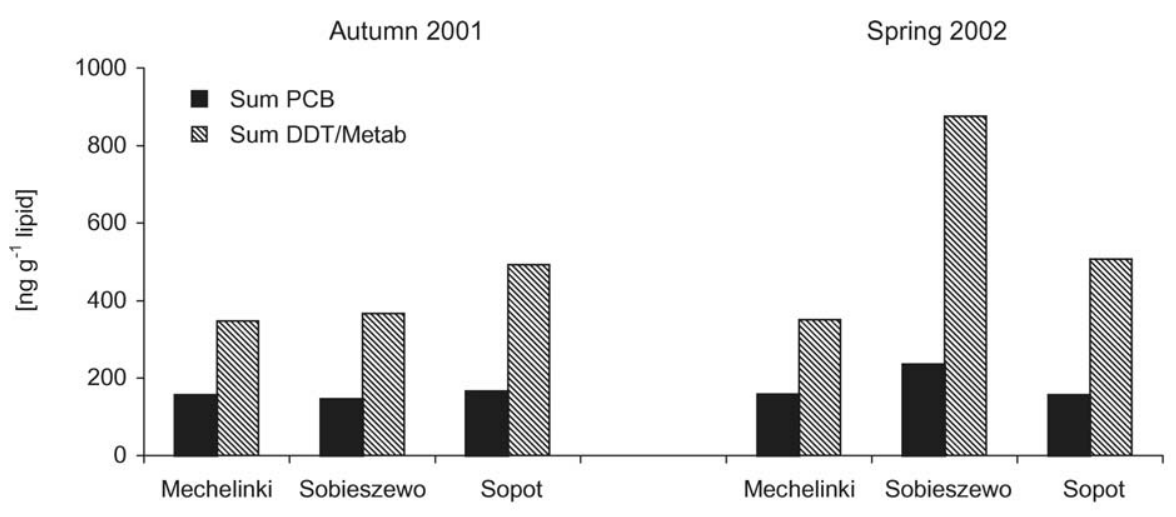

Autumn 2001

Spring 2002

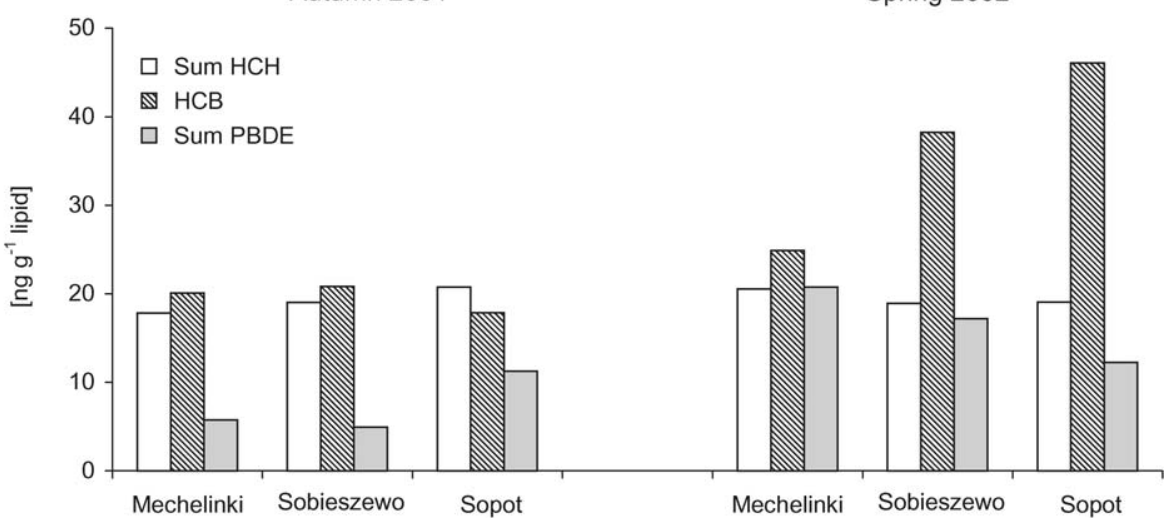

Fig. 5. Platichthys flesus. Levels of selected POPs ( $\mathrm{ng} \mathrm{g}^{-1}$ lipid wt) in the muscle tissue at the three study stations in the Gulf of Gdańsk in autumn 2001 and spring 2002.

Table 3

Platichthys flesus; Pearson's linear correlation coefficients on biomarkers and gross morphometric indices vs. concentrations of selected POPs (PCBs, HCHs, HCBs, DDT metabolites and PBDE ( $\mathrm{ng} \mathrm{g}^{-1}$ lipid)) in the muscle tissue of individual flounders collected in autumn 2001 (A2001) and spring 2002 (S2002)

Pearson correlation coefficient between parameter and tissue contaminant level

\begin{tabular}{|c|c|c|c|c|c|c|c|c|c|c|c|c|}
\hline $\begin{array}{l}\text { Contaminant } \\
\text { Sampling }\end{array}$ & \multicolumn{2}{|l|}{$\sum \mathrm{PCB}$} & \multicolumn{2}{|c|}{$\sum \mathrm{HCH}$} & \multicolumn{2}{|l|}{$\mathrm{HCB}$} & \multicolumn{2}{|c|}{$\sum \mathrm{DDT}$} & \multicolumn{2}{|c|}{$\sum \mathrm{PBDE}$} & \multicolumn{2}{|c|}{$\sum$ POPs } \\
\hline \multicolumn{13}{|l|}{ Parameter } \\
\hline HSI & 0.14 & -0.39 & 0.16 & 0.11 & 0.15 & 0.26 & 0.26 & -0.36 & 0.27 & -0.58 & 0.24 & -0.36 \\
\hline GSI & 0.59 & 0.87 & 0.55 & -0.68 & 0.20 & 0.13 & 0.47 & 0.62 & 0.34 & 0.51 & 0.55 & 0.68 \\
\hline $\mathrm{AChE}$ & -0.74 & 0.42 & -0.47 & -0.33 & -0.33 & 0.19 & -0.66 & 0.19 & -0.43 & 0.01 & -0.72 & 0.24 \\
\hline CAT & 0.70 & -0.39 & 0.46 & 0.63 & 0.33 & -0.45 & 0.95 & -0.21 & 0.63 & -0.54 & 0.90 & -0.27 \\
\hline $\mathrm{MN}$ & -0.11 & -0.57 & -0.02 & 0.33 & -0.05 & -0.19 & -0.23 & -0.47 & -0.28 & -0.41 & -0.12 & -0.50 \\
\hline MT & & 0.33 & & -0.24 & & -0.11 & & 0.40 & & 0.30 & & 0.39 \\
\hline VTG & & 0.67 & & -0.55 & & 0.03 & & 0.38 & & 0.63 & & 0.44 \\
\hline LMS & & -0.40 & & 0.38 & & 0.07 & & -0.47 & & -0.45 & & -0.45 \\
\hline FAC & & 0.62 & & -0.51 & & 0.24 & & 0.53 & & 0.15 & & 0.56 \\
\hline
\end{tabular}

Statistically significant correlations $(p<0.05)$ are given in bold. In autumn $2001 n=9$, in spring $2002 n=14$. Note: in regard to AChE and LMS a negative correlation indicates a higher response at higher tissue concentrations.

temperate areas; therefore, their influence on certain biomarker responses can be expected to be greater.
Dizer et al. (2001) observed the mean AChE activity in flounder collected in November from the Pomeranian 
Bay (southern Baltic Sea) to vary between 60 and $102 \mathrm{nmol} \mathrm{min}^{-1} \mathrm{mg}$ protein ${ }^{-1}$, which falls within the range reported in the present study. Differences in AChE activity observed here could partly be explained by the high nearbottom temperatures recorded in autumn $2001\left(10-14{ }^{\circ} \mathrm{C}\right)$ compared to autumn 2002 and springs 2002 and 2003 (see Table 1), because temperature can affect both contaminant concentrations and physiological activity of fish (Hogan, 1970; Bocquené et al., 1990; Bocquené and Galgani, 1998). Parallel to the present work, Napierska and Podolska (2005) studied seasonal (autumnal) differences in AChE activities in flounder from the Gulf of Gdańsk. Also they recorded a markedly higher AChE activity in autumn 2001 compared to the autumns of 2002 and 2003 , attributing the interannual variability to differences in water temperature.

The seasonal variability in EROD activity in female flounder observed in this study has also been reported in the North Sea (Broeg et al., 1999) with seasonal values in the same range as those measured here (autumn: 20850 pmol min $^{-1} \mathrm{mg}_{\text {protein }}{ }^{-1}$, spring: $100-2900 \mathrm{pmol}$ $\min ^{-1} \mathrm{mg}$ protein ${ }^{-1}$ ). Draganik et al. (1996) measured substantially higher EROD activities (up to $1898 \mathrm{pmol}$ $\min ^{-1} \mathrm{mg} \mathrm{protein}^{-1}$ ) in flounder from the Gulf of Gdańsk in February 1996, which suggests that pollution levels in the area might have been higher during that time. However, it is possible that these results obtained in February are more comparable to those of April (2002) in the present study when high values were also measured (station means between 1198 and $2198 \mathrm{pmol} \mathrm{min}^{-1} \mathrm{mg}_{\text {protein }}{ }^{-1}$ ) rather than October 2002 when much lower values were recorded (station means between 179 and 211 pmol min $^{-1} \mathrm{mg}$ protein $^{-1}$ ). The observed differences in EROD activity can be caused by variable stages of gonad maturity or HSI, which has been proposed by Whyte et al. (2000) as an "exposure index" to contaminants. In the Baltic the flounder spawns in winter, and the high EROD activity recorded here in spring can therefore be interpreted as resulting from spawning stress as noted elsewhere (Eggens et al., 1995, 1996; Kirby et al., 1999; Rotchell et al., 1999). Immature flounder have been recorded to show higher EROD activity than mature ones (Eggens et al., 1995; Draganik et al., 1996). In the present study the length range of the flounders studied was $24-30 \mathrm{~cm}$ and the specimens can therefore be considered mature. Conclusively, seasonal variability related mainly to the reproductive cycle affects markedly the levels of EROD activity in flounder from the Gulf of Gdańsk.

In the present study the spatial pattern of EROD activity was inconsistent. This may reflect the migratory nature of flounder and the mixing of stocks exposed to pollution in different areas, and differential gonad stage development of individuals. The data also imply that males have a higher EROD activity than females. In flounder, but also in other species, Förlin et al. (1984) reported similar patterns of a higher mono-oxygenase activity and total cytochrome P450 content in mature males compared to mature females. Gonadal sex steroids have been suggested to play an impor- tant role in the regulation of gender-dependent differences in cytochrome P450 mediated metabolism of xenobiotics in fish (Förlin et al., 1984). Conclusively, the observed seasonal differences indicating strong season-dependent temporal trends in EROD activity imply that the timing of sample collection is a crucial factor when this biomarker is used in monitoring programmes.

In regard to seasonal levels of VTG in mature female flounder, Kleinkauf et al. (2004c), measured very low concentrations of VTG in summer compared to winter from the Mersey Estuary (UK). In this study, 3-4 times higher VTG levels in female flounder at the Mechelinki and Sobieszewo stations were observed in autumn 2002 compared to those collected in Sopot. It is also noteworthy that HSI in females was markedly higher at the aforementioned sites during the period.

Bresler et al. (1999) observed seasonal changes in hepatic GST activity in flounder from the German North Sea but found no spatial variability. In Norwegian fjords, Beyer et al. (1996) reported GST activity in the flounder

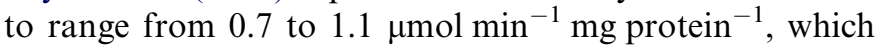
is at a substantially higher level than the values recorded in the present study. Also Vigano et al. (2001) reported slightly higher activities (mean $0.320 \mu \mathrm{mol} \mathrm{min}{ }^{-1} \mathrm{mg}$ protein $^{-1}$ ) in a laboratory experiment using flounder from the northern Adriatic Sea. Possible reasons for these differences include the effects of higher salinity and/or, in the case of the latter study, smaller individual size of specimens from the Adriatic Sea compared with flounder from the Gulf of Gdańsk.

In regard to CAT activity and LMS in the Baltic flounder little or no seasonal data is available for relevant comparisons. Broeg et al. (1999) reported a wider range but generally higher lysosomal destabilisation times in flounder from the North Sea (spring samples: 2-35 min, autumn samples: 3-30 $\mathrm{min}$ ) compared to those determined here (spring 2002: 6.2-10.3 min, autumn 2002: 6.6-10.2 $\mathrm{min}$ ). LMS data obtained for flounder from the two main regions, the Baltic and North Seas, are not markedly influenced by season but mainly by the sampling location. The lowest LMS values reported here during the spring and autumn campaigns of 2002 were recorded in flounder from Sobieszewo, the site close to the mouth of the Vistula River, indicating a deteriorated condition of the flounder population residing in this area.

Although no real between-site differences could be detected in the levels of MT they were almost twofold higher in specimens collected in autumn compared to spring at all study stations. Similar seasonal variability in MT levels was recorded in flounder collected during the BEEP project from the Lithuanian coast (Baršiene et al., 2006a). Thus, although differential exposure to pollutants during the season and the migration behaviour of the species likely play a major role, the ubiquitous seasonal changes observed are probably strongly related to endogenous metal homeostasis regulation during different stages of the reproductive cycle. 
Comparison of $\mathrm{MN}$ frequency in flounder from different localities of the Gulf of Gdańsk revealed a comparatively low level of genotoxicity in individuals inhabiting the original "reference" station Sopot (0.31 MN 1000 erythrocytes $^{-1}$ ) and an elevated response in individuals from Mechelinki and Sobieszewo (up to $0.66 \mathrm{MN} 1000$ erythrocytes $\left.^{-1}\right)$. Genotoxicity of numerous organic substances in aquatic environment is associated with particulate matter while others are distributed in the water-soluble fraction (Claxton and Houk, 1998). Elevated levels of MN were detected in flounder and mussels even 8 months after the crude oil spill at the Būtinge oil terminal (Baršienè et al., 2004). Following the "Exxon Valdez" oil spill in Prince William Sound in March 1989, anaphase aberrations in fish embryos showed a correlation with concentrations of PAHs within the oil trajectory (Hose and Brown, 1998). In addition, more frequent chromosomal aberrations and malformations have been observed in cod (Gadus morhua) and pollock (Pollachius virens) embryos from an area contaminated by an oil spill (Longwell, 1977). In regard to PAH metabolites in bile similar levels (3-9 F.U.) were reported by Baršiene et al. (2006a) in flounder off the open-sea Lithuanian coast suggesting that PAH contamination is at a similar level in the two areas.

Results from the PCA illustrate some of the difficulties in distinguishing the influence of contamination from that of natural variability in the levels of many biomarkers. The potential impact of pollution can often be seen during one season (e.g. in spring or autumn) or during one sampling campaign, but when the biomarker levels of a twoyear or longer study are evaluated the effects of contamination are often masked by seasonal and/or year-to-year variability.

The selected data on flounder used here for PCA indicates that Sopot, the site considered the least contaminated (Pazdro, 2004), is completely separated from the more contaminated site Sobieszewo, while station Mechelinki is partly separated from the two others (Fig. 4c). The separation between Mechelinki and Sobieszewo is much less clear. In general, the PCA results suggest that flounder probably is a less suitable organism for geographically small-scale monitoring (point sources) because, due to stock mixing, the results may represent specimens originating from a potentially large area. Therefore, to prevent stock mixing effects on the detection of pollution it can be recommended that the distances between the sampling sites for flounder should be sufficiently large.

The data obtained from the analyses of organic contaminants from flounder muscle tissues did not follow the expected pollution gradient basing on which the study sites in the Gulf of Gdańsk were originally selected. Because of the lack of clear contaminant gradients and small differences in concentrations observed between the sites the data are difficult to link straightforwardly to the biomarker responses observed.

PCBs and PAHs have been reported to occur only in moderate concentrations in the sediments of the Gulf of
Gdańsk (Kowalewska and Konat, 1997; Konat and Kowalewska, 2001; Pazdro, 2004). Pazdro (2004) reported the lowest $\sum$ PAH, $\sum$ PCB and DDT concentrations at the Sopot site compared to a reference site outside the Hel Peninsula. Albalat et al. (2002) and Potrykus et al. (2003) reported high concentrations of $\sum \mathrm{PAH}, \sum \mathrm{PCB}$ and DDTs in mussels as well as organotins in mussels and flounder in the vicinity of the Vistula River mouth and the Gdynia harbour (close to station Mechelinki). Different PAHs, PCBs and chlorinated pesticides have also been detected in mussels from this area (Potrykus et al., 2003). However, the tissue concentrations measured in flounder collected during this study do not agree well with these previous results.

A possible explanation for the observed variability in biomarker responses in flounder is that the concentrations of POPs in the sediments and biota of the Gulf of Gdańsk can in general be considered low in comparison with other marine coastal areas of industrialised regions (Bouloubassi and Saliot, 1991; Van Zoest and Van Eck, 1993; Fava et al., 2003; Potrykus et al., 2003; Pazdro, 2004) and therefore elicit only low biomarker responses. Furthermore, a statistically significant value of a correlation coefficient indicates that the hypothesis on the dependence between a contaminant and a given biomarker cannot be excluded, i.e. they may or may not be dependent. In this study, tissue concentrations of some important contaminant groups, e.g. PAHs and heavy metals, were not determined. However, the statistically significant correlation between FACs in bile and $\sum$ PCB suggests that high levels of PAHs in the environment, revealed by the elevated metabolite concentrations, accompanied high tissue levels of PCBs. Finally, the $\mathrm{CF}$ of specimens was negatively correlated with most tissue contaminants, indicating a deteriorating influence of contaminant loads on the general health of fish.

\subsection{Factors influencing biomarker levels in mussels in the Gulf of Gdanisk}

In mussels from the southern and south-eastern Baltic Sea, comparable mean AChE activity levels to those recorded in the present study have been observed off the Lithuanian coast $\quad\left(25-37 \mathrm{nmol} \mathrm{min}^{-1} \mathrm{mg}\right.$ protein $^{-1}$; Baršiene et al., 2006a), but in the Wismar Bay (German Baltic coast) a much wider activity range was recorded (16-85 $\mathrm{nmol} \mathrm{min}^{-1} \mathrm{mg}$ protein $\left.{ }^{-1}\right)$ depending strongly on season and location (Schiedek et al., 2006). Romèo et al. (2003) observed no seasonal variability in the AChE activity of the mussel Mytilus galloprovincialis in the NW Mediterranean. However, seasonal variability in AChE in $M$. edulis was apparent in the 3-year monitoring programme elucidating the effects of the "Erika" wreck off Brittany (Bocquené et al., 2004). In the Baltic Sea, where seasonal variations in the marine environment are more extensive than in temperate seas, greater variability can be anticipated. AChE activity in mussels from the northern Baltic Sea have been shown to have marked seasonal variability likely related to several abiotic (temperature, salinity) and 
biotic (food abundance, reproductive stage) factors (Leiniö and Lehtonen, 2005), which themselves are characteristic for each geographical sub-region of the Baltic.

Dizer et al. (2001) noted no spatial differences in AChE activity of mussels collected from several coastal sites in the western Baltic Sea. In a nearby region, the Wismar Bay, inhibition of AChE activity in mussels followed the gradient of increasing tissue load of organochlorines (Schiedek et al., 2006), but this was not the case in two areas in the southern coast of Finland (Lehtonen et al., in press). In the present study, the low levels observed in AChE activity can in some cases be caused by unknown pesticides not measured in this study but may as well be attributed to other substances that have been shown to affect AChE activity (Payne et al., 1996; Guilhermino et al., 1998; Lehtonen et al., 2003). Whatever the type of contamination, the markedly lower AChE activities observed in mussels at Mechelinki compared to Sopot, both in autumn 2001 and spring 2002, indicate apparent biological effects at that site.

The mean GST activity of mussels ranged from 0.082 to $0.230 \mu \mathrm{mol} \mathrm{min}^{-1} \mathrm{mg}$ protein ${ }^{-1}$. In addition to pollution and seasonal variability also salinity may affect the levels of GST activity in mussels. In the low-salinity (6 PSU) Gulf of Finland (northern Baltic Sea), Leiniö and Lehtonen (2005) recorded a seasonal range from 0.162 to $0.472 \mu \mathrm{mol} \mathrm{min}^{-1} \mathrm{mg}$ protein ${ }^{-1}$ from sites considered relatively clean. In their study area, the seasonal pattern in GST activity was complex (e.g. poor correlation with changes in temperature) and evidently modulated by several abiotic and biotic factors. In the south coast of Ireland, Fitzpatrick et al. (1997) did not observe any significant seasonal changes in GST activity in mussels. No differences between sampling sites or any clear temporal seasonal trends for GST activity in mussels were observed from the western Mediterranean Sea by Porte et al. (2001), neither were they found in a lake and rivers in the Tucholski Landscape Park (central Poland) by Petushok et al. (2002). Seasonal changes in CAT activity in mussels have been reported by Solé et al. (1995), Regoli (1998), Narbonne et al. (1999) and Leiniö and Lehtonen (2005), all showing a higher CAT activity in spring compared to autumn, similar to this study. Bresler et al. (1999) observed no differences in GST activity levels of mussels measured from "clean" and polluted stations in the German part of the North Sea. The same was observed also for CAT activity in mussels off the Salento Peninsula (Italy) by Lionetto et al. (2003). However, both these authors suggest these findings to be caused by biochemical adaptation to chronic exposure to pollutants. In laboratory experiments, Suteau et al. (1988), Fitzpatrick et al. (1997) and Pempkowiak et al. (submitted for publication) recorded no response in GST activity in mussels exposed to various pollutants. In the present study neither GST nor CAT activities showed differences between the study sites, which could be interpreted as a homogenous distribution of contamination in the study area. However, most other results obtained in this study suggest different pollution levels at the sampling stations during each campaign and/or the effect of biotic and abiotic factors.

Baršienè et al. (2006a) reported MT levels in mussels off Lithuania to range from 180 to $310 \mu \mathrm{g} \mathrm{g}^{-1}$ wet wt (digestive gland), corresponding to those recorded in the present study. In the Wismar Bay the levels of MT were much lower (119-190 $\mu \mathrm{g} \mathrm{g}^{-1}$ wet wt; Schiedek et al., 2006). In the Gulf of Finland the seasonal range consists of even higher MT levels (239-359 $\mu \mathrm{g} \mathrm{g}^{-1}$ wet wt; Leiniö and Lehtonen, 2005). Since bioavailability of metals is well known to be salinity-dependent it is probable that the observed regional differences in MT levels in the Baltic Sea are, in addition to actual metal concentrations in the environment, also related to variability in the salinity regime. This further stresses the importance of taking into account regional differences and their effects on biomarker responses for correct interpretations.

In the present study it is of interest to note that while at the "reference" station Sopot the difference between the MT level in mussels measured in autumn was almost twofold higher compared to the levels measured in spring, the corresponding seasonal differences at the two more contaminated sites were much smaller, while significantly higher MT levels were recorded in Sobieszewo in spring. It appears that the mussels inhabiting these two locations regarded contaminated may suffer from metal or oxidative stress (Viarengo et al., 2000) but the exact causal agents or mechanisms of action are difficult to pinpoint with the data available.

The highest mean value of $\mathrm{MN}$ frequency $\left(6 \mathrm{MN} 1000\right.$ cells $\left.^{-1}\right)$ recorded here was the highest incidence recorded in mussels compared to all other populations studied in the Baltic Sea (Baršiene et al., 2006b). In the autumn samples very high frequencies of MN were detected in mussels from Sobieszewo and Sopot localities while in early spring 2002 a low response was measured at all study stations. During the latter period the water temperature ranged between $3.2-3.5^{\circ} \mathrm{C}$, and, as a result, very low mitotic activity (less than one mitosis per 1000 cells) and comparatively low amounts of micronucleated cells (from 2.07 to $2.11 \mathrm{MN} 1000 \mathrm{cells}^{-1}$ ) were registered in the gills of the mussels. In autumn 2001 mussels were collected twice (in October and November) from station Sobieszewo and the results confirmed the influence of water temperature on the frequency of $\mathrm{MN}$ in mussels with a higher incidence in specimens collected in October compared to November (Baršiene et al., 2006a). In the soft-bottom clam Macoma balthica high levels of cells with abnormal chromosome sets and high prevalence of tumours in the gill and digestive system have recently been reported in the Gulf of Gdańsk (Thiriot-Quievreux and Wołowicz, 2001; Sokołowski et al., 2004). Relationships between elevated tissue concentrations of heavy metals (As, $\mathrm{Ag}, \mathrm{Cd}, \mathrm{Pb}, \mathrm{Cu}$ and $\mathrm{Zn}$ ) in M. balthica and symptoms of environmental adversity in this area have been demonstrated (Sokołowski et al., 2004). 


\section{Conclusions}

In this study carried out in the inner part of the Gulf of Gdańsk the differences observed in a number of biomarker responses are largely attributable to natural physiological processes and/or variability in environmental hydrographic and climatic conditions during the season. However, they are at least partially caused by pollution due to e.g. differential exposure conditions between the locations and mobilisation of accumulated toxicants within the organism during specific physiological states (e.g. starvation, reproduction), meanwhile the different sensitivity of species and individuals to pollutants also contributes to the observed variability. According to the currently available data on the levels of anthropogenic contaminants the Gulf of Gdańsk on the whole is not considered as a heavily polluted area. Yet, the combination of biological effects and tissue contaminant data obtained in the present study could in many cases detect geographical differences related to the nature and degree of pollution within the study area.

\section{Acknowledgements}

This work was supported by a grant from the European Union on "Biological Effects of Environmental Pollution in Marine Coastal Ecosystems" (BEEP) (EVK3-CT-200000025). The authors wish to express their gratitude for the analyses of POPs to Ms Marsha Hanson (ITM, Stockholm), for the analysis of FACs to MSc Heta Vuontisjärvi (FGFRI, Helsinki) and to Dr. Jacek Bełdowski (IO-PAS, Sopot) for his help in PCA. Comments on the manuscript by Prof. Lars Förlin (Gothenburg University) and the useful comments made by two anonymous reviewers are gratefully acknowledged.

\section{References}

Albalat, A., Potrykus, J., Bełdowski, J., Pempkowiak, J., Porte, C., 2002. Assessment of organotin pollution along the Polish Coast (Baltic Sea) by using mussels and fish as sentinel organisms. Chemosphere 47 (2), $165-171$.

Ariese, F., Kok, S.J., Verkaik, M., Gooijer, C., Velthorst, N.H., Hofstraat, J.W., 1993. Synchronous fluorescence spectrometry of fish bile: a rapid screening method for the biomonitoring of PAH exposure. Aquatic Toxicology 26, 273-286.

Baršienè, J., Lazutka, J., Šyvokienė, J., Dedonytè, V., Rybakovas, A., Bjornstad, A., Andersen, O.K., 2004. Analysis of micronuclei in blue mussels and fish from the Baltic and the North Seas. Environmental Toxicology 19, 365-371.

Baršiene, J., Lehtonen, K.K., Köhler, A., Broeg, K., Vuorinen, P.J., Lang, T., Pempkowiak, J., Šyvokiene, J., Dedonyte, V., Rybakovas, A., Repečka, R., Vuontisjarvi, H., Kopecka, J., 2006a. Biomarker responses in flounder (Platichthys flesus) and mussel (Mytilus edulis) in the Klaipeda-Būtingè area (Baltic Sea). Marine Pollution Bulletin (this volume).

Baršienè, J., Syvokienè, J., Rybakovas, A., Schiedek, D., Kopecka, J., Förlin, L., 2006b. Cytogenetic and cytotoxic effects in gill cells of the blue mussel Mytilus spp. from different zones of the Baltic Sea. Marine Pollution Bulletin (this volume).

Beyer, J., Sandvik, M., Hylland, K., Fjeld, E., Egaas, E., Aas, E., Skåre, J.U., Goksøyr, A., 1996. Contaminant accumulation and biomarker responses in flounder (Platichthys flesus L.) and Atlantic cod (Gadus morhua L.) exposed by caging to polluted sediments in Sørfjorden, Norway. Aquatic Toxicology 36, 75-98.

Bocquene, G., Galgani, F., 1998. Biological effects of contaminants: cholinesterase inhibition by organophosphate and carbamate compounds. ICES Techniques in Marine Environmental Sciences No. 22. International Council for the Exploration of the Sea, pp. 1-13.

Bocquené, G., Galgani, F., Truquet, P., 1990. Characterization and assay conditions for use of AChE activity from several marine species in pollution monitoring. Marine Environmental Research 30, 75-89.

Bocquené, G., Chantereau, S., Clérendeau, C., Beausir, E., Ménard, D., Raffin, B., Minier, C., Burgeot, T., Pfohl Leskowicz, A., Narbonne, J.F., 2004. Biological effects of the "Erika" oil spill on the common mussel (Mytilus edulis). Aquatic Living Resources 17, 309-316.

Bouloubassi, I., Saliot, A., 1991. Sources and transport of hydrocarbons in the Rhône delta sediments (North-Western Mediterranean). Fresenius Zeitschrift für Analytische Chemie 339, 765-771.

Bradford, M., 1976. A rapid method quantification of protein utilizing the principle dyebinding. Analytical Biochemistry 72, 248-264.

Bresler, V., Bissinger, V., Abelson, A., Dizer, H., Sturm, A., Kratke, R., Fischelson, L., Hansen, P.-D., 1999. Marine molluscs and fish as biomarkers of pollution stress in littoral regions of the Red Sea, Mediterranean Sea and North Sea. Helgoland Marine Research 53 (3-4), 219-243.

Broeg, K., Zander, S., Diamant, A., Körting, W., Krüner, G., Paperna, I., von Westernhagen, H., 1999. The use of fish metabolic, pathological and parasitological indices in pollution monitoring. I - North Sea. Helgoland Marine Research 53 (3-4), 171-194.

Bucheli, T.D., Fent, K., 1995. Induction of cytochrome P450 as a biomarker for environmental contamination in aquatic ecosystems. Critical Reviews in Environmental Science and Technology 25 (3), 201-268.

Burgeot, T., Bocquené, G., His, E., Vincent, F., Geffard, O., Beiras, R., Goraguer, H., Galgani, F., 2001. Monitoring of biological effects of pollutants: field application. In: Garrigues, P., Barth, H., Walker, C.H., Narbonne, J.F. (Eds.), Biomarkers in Marine Organisms, A Practical Approach, BIOMAR. Elsevier, Amsterdam, pp. 179-213.

Burke, M.D., Mayer, R.T., 1974. Ethoxyresorufin: direct fluorometric assay of a microsomal $O$-dealkylation which is preferentially inducible by 3-methylcholanthrene. Drug Metabolism and Disposition 2, 583588.

Claiborne, A., 1985. Catalase activity. In: Greenwald, R.A. (Ed.), Handbook of Methods for Oxygen Radical Research. CRC Press, Boca Raton, FL, pp. 283-284.

Clark, A.G., 1989. The comparative enzymology of the glutathione- $S$ transferase from non-vertebrate organisms. Review. Comparative Biochemistry and Physiology Part B 92 (3), 419-446.

Claxton, L.D., Houk, V.S., 1998. Genotoxicity of industrial wastes and effluents. Mutagenic Research 410, 237-243.

Dizer, H., da Silva de Assis, H.C., Hansen, P.-D., 2001. Cholinesterase activity as a bioindicator for monitoring marine pollution in the Baltic Sea and the Mediterranean Sea. In: Garrigues, P., Barth, H., Walker, C.H., Narbonne, J.F. (Eds.), Biomarkers in Marine Organisms, A Practical Approach, BIOMAR. Elsevier, Amsterdam, pp. 331-342.

Draganik, B., Bykowski, P., Krawczak-Krogulecka, W., Kuczyński, J., 1996. Seasonal and spatial variation in EROD activity in flounder along the Polish coast. Bulletin of Sea Fisheries Institute 2 (138), $3-13$.

Eggens, M., Bergman, A., Vethaak, D., 1995. Seasonal variation of hepatic EROD activity in flounder (Platichthys flesus) in the Dutch Wadden Sea. Marine Environmental Research 39, 231-234.

Eggens, M.L., Opperhuizen, A., Boon, J.P., 1996. Temporal variation of CYP1A indices, PCB and 1-OH pyrene concentration in flounder, Platichthys flesus, from the Dutch Wadden Sea. Chemosphere 33, 1579-1596.

Ellman, G.L., Courtney, K.O., Andres, V., Featherstone, R.M., 1961. A new and rapid colorimetric determination of acetylcholinoesterase activity. Biochemical Pharmacology 7, 88-95. 
Escartin, E., Porte, C., 1997. The use of cholinesterase and carboxylesterase activities from Mytilus galloprovincialis in pollution monitoring. Environmental Toxicology and Chemistry 16 (10), 2090-2095.

Fava, F., Gentilucci, S., Zanaroli, G., 2003. Anaerobic biodegradation of weathered polychlorinated biphenyls (PCBs) in contaminated sediments of Porto Maghera. Chemosphere 53, 101-109.

Fitzpatrick, P.J., O'Halloran, J., Sheehan, D., Walsh, A.R., 1997. Assessment of a glutathione $S$-transferase and related proteins in the gill and digestive gland of Mytilus edulis (L.), as potential organic pollution biomarkers. Biomarkers 2, 51-56.

Förlin, L., Andersson, T., Koivusaari, U., Hansson, T., 1984. Influence of biological and environmental factors on hepatic steroid and xenobiotic metabolism in fish: interaction with PCB and $\beta$-naphthoflavone. Marine Environmental Research 14, 47-58.

Galgani, F., Payne, J., 1991. Biological effects of contaminants: microplate method for measurement of ethoxyresorufin- $O$-deethylase (EROD) in fish. ICES Techniques in Marine Environmental Sciences No. 13, p. 11.

Gercken, J., Förlin, L., Andersson, J., 2006. Developmental disorders in larvae of eelpout (Zoarces viviparus) from German and Swedish Baltic coastal waters. Marine Pollution Bulletin (this volume).

Goksøyr, A., Beyer, J., Egaas, E., Grøsvik, B.E., Hylland, K., Sandvik, M., Skaare, J.U., 1996. Biomarker responses in flounder (Platichthys flesus) and their use in pollution monitoring. Marine Pollution Bulletin 33 (1-6), 36-45.

Guilhermino, L., Barros, B., Silva, M.C., Soares, A.M.V.M., 1998. Should the use of inhibition of cholinesterases as a specific biomarker for organophosphate and carbamate pesticides be questioned? Biomarkers 3, 157-163.

Habig, W.H., Pabst, M.J., Jakoby, W.B., 1974. Glutathione-S-transferases. The first enzymatic step in mercapturic acid formation. Journal of Biological Chemistry 249 (22), 7130-7139.

Haux, C., Förlin, L., 1988. Biochemical methods for detecting effects of contaminants on fish. Ambio 17 (6), 376-380.

Hogan, J.W., 1970. Water temperature as a source of variation in specific activity of brain acetylcholinesterase of bluegills. Bulletin of Environmental Contamination and Toxicology 5 (4), 347-353.

Hose, J.E., Brown, E.D., 1998. Field applications of the piscine anaphase aberration test: lessons from the Exxon Valdez oil spill. Mutagenic Research 399, 167-178.

ICES WGBEC, 2004. Report of the Working Group on Biological Effects of Contaminants, 22-26 March 2004, Ostend, Belgium. ICES Marine Habitat Committee. ICES CM 2004/E:04 Ref. ACME, p. 86.

Kirby, M.F., Matthiessen, P., Neall, P., Tylor, T., Allchin, C.R., Kelly, C.A., Maxwell, D.L., Thain, J.E., 1999. Hepatic EROD activity in flounder (Platichthys flesus L.) as an indicator of contaminant exposure in English estuaries. Marine Pollution Bulletin 38 (8), 676686.

Kleinkauf, A., Macfarlane, C., Yeates, S., Simpson, M.G., Leah, R.T., 2004a. A biomarker approach to endocrine disruption in flounder estrogen receptors, hepatocyte proliferation, and sperm motility. Ecotoxicology and Environmental Safety 58, 324-334.

Kleinkauf, A., Connor, L., Swarbreck, D., Levene, C., Walker, P., Johnson, P.J., Leah, R.T., 2004b. General condition biomarkers in relation to contaminant burden in European flounder (Platichthys flesus). Rapid communication. Ecotoxicology and Environmental Safety 58, 335-355.

Kleinkauf, A., Scott, A.P., Stewart, C., Simpson, M.G., Leah, R.T., 2004c. Abnormally elevated VTG concentration in flounder (Platichthys flesus) from the Mersey Estuary (UK) - a continuing problem. Rapid communication. Ecotoxicology and Environmental Safety 58, 356-364.

Köhler, A., Pluta, H.J., 1995. Lysosomal injury and MFO activity in the liver of flounder (Platichthys flesus) in relation to histopathology of hepatic degeneration and carcinogenesis. Journal of Environmental Health 39, 256-260.

Köhler, A., Soeffker, K., Wahl, E., 2002. Functional and morphological changes of lysosomes as prognostic biomarker of toxic injury in a marine flatfish Platichthys flesus (L.). Environmental Toxicology and Chemistry 21, 2434-2444.

Konat, J., Kowalewska, G., 2001. Polychlorinated biphenyls (PCBs) in sediments of the southern Baltic Sea - trends and fate. The Science of the Total Environment 280, 1-15.

Kopecka, J., Pempkowiak, J., 2002. AChE as biomarker of mussels and fish contamination with chemicals in the Gulf of Gdańsk. Poster presentation at the SETAC 2002 Conference Vienna 2002. Book of Abstracts, p. 223.

Kopecka, J., Pempkowiak, J., 2003. The feasibility of AChE, GST and CAT as biomarker of bivalvia contamination with chemicals in the Gulf of Gdańsk. Poster presentation at the SETAC 2003 Conference Hamburg 2003. Book of Abstracts, p. 135.

Kopecka, J., Pempkowiak, J., 2004. AChE as biomarker of mussels and fish contamination with chemicals in the Gulf of Gdańsk. Annual Set The Environment Protection 6, 99-106.

Kopecka, J., Rybakovas, A., Baršiene, J., Pempkowiak, J., 2004. AChE levels in mussels and fish collected off Lithuania and Poland (southern Baltic). Oceanologia 46 (3), 405-418.

Koslowski, S.E., Metcalfe, C.D., Lazar, R., Haffner, G.D., 1994. The distribution of $42 \mathrm{PCBs}$, including three coplanar congeners, in the food web of the western basin of Lake Erie. Journal of Great Lakes Research 20 (1), 260-270.

Kowalewska, G., Konat, J., 1997. Distribution of polynuclear aromatic hydrocarbons (PAHs) in sediments of the southern Baltic Sea. Oceanologia 39, 83-104.

Lehtonen, K.K., Schiedek, D., 2006. Monitoring biological effects of pollution in the Baltic Sea: neglected - but still wanted? Marine Pollution Bulletin (this volume).

Lehtonen, K.K., Kankaanpää, H., Leiniö, S., Sipiä, V.O., Pflugmacher, S., Sandberg-Kilpi, E., 2003. Accumulation of nodularin-like compounds from the cyanobacterium Nodularia spumigena and changes in acetylcholinesterase activity in the clam Macoma balthica during shortterm laboratory exposure. Aquatic Toxicology 64, 461-476.

Lehtonen, K.K., Leiniö, S., Schneider, R., Leivuori, M., in press. Biomarkers of pollution effects in the bivalves Mytilus edulis and Macoma balthica collected from two areas in the southern coast of Finland (Baltic Sea). Marine Ecology Progress Series.

Leiniö, S., Lehtonen, K.K., 2005. Seasonal variability in biomarkers in the bivalves Macoma balthica and Mytilus edulis from the northern Baltic Sea. Comparative Biochemistry and Physiology C 140, 408-421.

Lionetto, M.G., Caricato, R., Giordano, M.E., Pascariello, M.F., Marinosci, L., Schettino, T., 2003. Integrated use of biomarkers (acetylcholinesterase and antioxidant enzymes activities) in Mytilus galloprovincialis and Mullus barbatus in an Italian coastal marine area. Marine Pollution Bulletin 46, 324-330.

Livingstone, D.R., 1993. Biotechnology and pollution monitoring: use of molecular biomarkers in the aquatic environment. Review. Journal of Chemical Technology and Biotechnology 57, 195-211.

Livingstone, D.R., Donkin, P., Walker, C.H., 1992. Pollutants in marine ecosystems: an overview. In: Walker, C., Livingstone, D.R. (Eds.), Persistent Pollutants in Marine Ecosystems, SETAC Special Publications Series. Pergamon Press, pp. 235-263.

Longwell, A.C., 1977. A genetic look at fish eggs and oil. Oceanus 20, 4648.

Mayer, F.L., Versteeg, D.J., McKee, M.J., Folmar, L.C., Graney, R.L., McCume, D.C., Rattner, B.A., 1992. Physiological and nonspecific biomarkers. In: Huggett, R.J., Kimerle, R.A., Mehrle, P.M., Jr., Bergman, H.L. (Eds.), Biomarkers - Biochemical, Physiological and Histological Markers of Anthropogenic Stress, SETAC Special Publication Series. Lewis Publisher, pp. 5-85.

McCarthy, J.F., Shugart, L.R., 1990. Biological markers of environmental contamination. In: McCarthy, J.F., Shugart, L.R. (Eds.), Biomarkers of Environmental Contamination. Lewis Publisher, Boca Raton, FL, pp. 3-16.

Melancon, M.J., Alscher, R., Benson, W., Kruzynski, G., Lee, R.F., Sikka, H.C., Spies, R.B., 1992. Metabolic products as biomarkers. In: Huggett, R.J., Kimerle, R.A., Mehrle, P.M., Jr., Bergman, H.L. (Eds.), 
Biomarkers - Biochemical, Physiological and Histological Markers of Anthropogenic Stress, SETAC Special Publication Series. Lewis Publisher, pp. 87-123.

Napierska, D., Podolska, M., 2003a. Preliminary results of AChE and GST measurements in flounder Platichthys flesus from the southern Baltic Sea. Bulletin of the Sea Fisheries Institute 2 (159), 51-66.

Napierska, D., Podolska, M., 2003b. Preliminary results of AChE, GST and EROD measurements in flounder Platichthys flesus and eelpout Zoarces viviparus from the southern Baltic Sea. Poster presentation at the BSSC Congress, Helsinki, 2003. Book of Abstracts, p. 196.

Napierska, D., Podolska, M., 2005. Biomarkers of contaminant exposure: results of a field study with flounder (Platichthys flesus) from the southern Baltic Sea. Marine Pollution Bulletin 50, 758-767.

Narbonne, J.F., Daubèze, M., Clèrendeau, C., Garrigues, P., 1999. Scale of classification based on biochemical markers in mussels: application to pollution monitoring in European coasts. Biomarkers 4 (6), 415-424.

Payne, J.F., Mathieu, A., Melvin, W., Fancey, L.L., 1996. Acetylcholinesterase, an old biomarker with a new future? Field trials in association with two urban rivers and a paper mill in Newfoundland. Marine Pollution Bulletin 32 (2), 225-231.

Pazdro, K., 2004. Persistent organic pollutants in sediments from the Gulf of Gdańsk. Annual Set The Environment Protection 6, 63-76.

Peakall, D., 1992. Animal Biomarkers as Pollution IndicatorsEcotoxicology Series 1. Chapman \& Hall, London, 291 p.

Pellerin-Massicotte, J., 1994. Oxidative processes as indicators of chemical stress in marine bivalves. Journal of Aquatic Ecosystem Health 3, 101111.

Pempkowiak, J., Pazdro, K., Kopecka, J., Perez, E., Sole, M., submitted for publication. Toxicants accumulation rates and effects in Mytilus trossulus and Nereis diversicolor exposed separately or together to cadmium and PAHs. Marine Environmental Research.

Petushok, N., Gabryelak, T., Pałecz, D., Zavodnik, L., Szollosi Varga, I., Deèr, K.A., 2002. Comparative study of the xenobiotic metabolizing system in the digestive gland of the bivalve mollusks in different aquatic ecosystems and in aquaria experiments. Aquatic Toxicology 61, 65-72.

Porte, C., Solé, M., Borghi, V., Martinez, M., Chamorro, J., Torreblanca, A., Ortiz, M., Orbea, A., Soto, M., Cajaraville, M.P., 2001. Chemical, biochemical and cellular responses in the digestive gland of the mussel Mytilus galloprovincialis from the Spanish Mediterranean coast. Biomarkers 6 (5), 335-350.

Potrykus, J., Albalat, A., Pempkowiak, J., Porte, C., 2003. Content and pattern of organic pollutants (PAHs, PCbs and DDT) in blue mussels (Mytilus trossulus) from the southern Baltic Sea. Oceanologia 45 (2), 337-355.

Regoli, F., 1998. Trace metals and antioxidant enzymes in gills and digestive gland of the Mediterranean mussel Mytilus galloprovincialis. Archives of Environmental Contamination and Toxicology 34, 48-63.

Regoli, F., Principato, G., 1995. Glutathione, glutathione-dependent and antioxidant enzymes in mussel, Mytilus galloprovincialis, exposed to metals under field and laboratory conditions implications or the use of biochemical biomarkers. Aquatic Toxicology 31, 143-164.

Roesijadi, G., 1992. Metallothioneins in metal regulation and toxicity in aquatic animals. Review. Aquatic Toxicology 22, 81-114.

Romèo, M., Hoarau, P., Garello, G., Gnassia-Barelli, M., Girard, J.P., 2003. Mussel transplantation and biomarkers as useful tools for assessing water quality in the NW Mediterranean. Environmental Pollution 12, 369-378.

Rotchell, J.M., Bird, D.J., Newton, L.C., 1999. Seasonal variation in ethoxyresorufin $O$-deethylase (EROD) activity in European eels Anguilla anguilla and flounders Pleuronectes flesus from the Severn Estuary and Bristol Channel. Marine Ecology Progress Series 190, 263-270.

Schiedek, D., Broeg, K., Baršiene, J., Lehtonen, K.K., Gercken, J., Pfeifer, S., Vuontisjärvi, H., Vuorinen, P.J., Dedonyte, V., Koehler, A., Balk, L., Schneider, R., 2006. Biomarker responses as indication of contaminant effects in blue mussel (Mytilus edulis) and female eelpout
(Zoarces viviparus) from the southwestern Baltic Sea. Marine Pollution Bulletin (this volume).

Sijm, D.T.H.M., Opperhuizen, A., 1989. Biotransformation of organic chemicals by fish: enzyme activities and reactions. In: Hutzinger, O. (Ed.), Reations and Processes, The Handbook of Environmental Chemistry, vol. 2E. Springer-Verlag, pp. 163-235.

Sokołowski, A., Wołowicz, M., Hummel, H., Smolarz-Górska, K., Fichet, D., Radenac, G., Thiriot-Quievreux, C., Namieśnik, J., 2004. Abnormal features of Macoma balthica (Bivalvia) in the Baltic Sea: alerting symptoms of environmental adversity? Marine Pollution Bulletin 49, $17-22$.

Solé, M., Porte, C., Albaigés, J., 1995. Seasonal variation in the mixedfunction oxygenase system and antioxidant enzymes of the mussel Mytilus galloprovincialis. Environmental Toxicology and Chemistry 14 (1), 157-164.

Stagg, R.M., McIntosh, A.D., 1998. Biological effects of contaminants: determination of CYP1A-dependent mono-oxygenase activity in dab by fluorometric measurements of EROD activity. ICES Techniques in Marine Environmental Sciences No. 23, p. 16.

Stegeman, J.J., Brouwer, M., Di Giulio, R.T., Förlin, L., Fowler, B.A., Sanders, B.M., Van Veld, P.A., 1992. Enzyme and protein synthesis as indicator of contaminant exposure and effect. In: Huggett, R.R., Kimerle, R.A., Mehrle, P.M., Jr., Bergman, H.L. (Eds.), Biomarkers Biochemical, Physiological and Histological Markers of Anthropogenic Stress, SETAC Special Publication Series. Lewis Publishers, pp. 235-334.

Suteau, P., Daubèze, M., Migaud, M.L., Narbonne, J.F., 1988. PAHmetabolizing enzymes in whole mussels as biochemical tests for chemical pollution monitoring. Marine Ecology Progress Series 46, 4549.

Thiriot-Quievreux, C., Wołowicz, M., 2001. Chromosomal study of spatial variation of the prevalence of a gill neoplasia in Macoma balthica (L.) from the Gulf of Gdańsk (Baltic Sea). Ophelia 54, 75-81.

van der Oost, R., Beyer, J., Vermeulen, N.P.E., 2003. Fish bioaccumulation and biomarkers in environmental risk assessment: a review. Environmental Toxicology and Pharmacology 13, 57-149.

Van Zoest, R., Van Eck, G.T., 1993. Historical input and behaviour of hexachlorobenzene, polychlorinated biphenyls and polycyclic aromatic hydrocarbons in two dated sediment cores from the Scheldt Estuary, SW, Netherlands. Marine Chemistry 44, 95-103.

Viarengo, A., Ponzano, E., Dondero, F., Fabbri, R., 1997. A simple spectrophotometric method for metallothionein evaluation in marine organisms: an application to Mediterranean and Antarctic molluscs. Marine Environmental Research 44, 69-84.

Viarengo, A., Burlano, B., Dondero, F., Marro, A., Fabbro, R., 1999. Metallothionein as a tool in biomonitoring programmes. Biomarkers 4, 455-466.

Viarengo, A., Burlando, B., Ceratto, N., Panfoli, I., 2000. Antioxidant role of metallothioneins: a comparative overview. Cellular Molecular Biology 46, 407-417.

Vigano, L., Arillo, A., Falugi, C., Melodia, F., Polesello, S., 2001. Biomarkers of exposure and effect in flounder (Platichthys flesus) exposed to sediment of the Adriatic Sea. Marine Pollution Bulletin 4 (10), 887-894.

Vuontisjärvi, H., Keinänen, M., Peltonen, K., Vuorinen, P.J., 2004. A comparison of HPLC with fluorescence detection and fixed wavelength fluorescence methods for the determination of polycyclic aromatic hydrocarbon metabolites in fish bile. Polycyclic Aromatic Compounds 24, 333-342.

Vuorinen, P.J., Keinänen, M., Vuontisjärvi, H., Baršienè, J., Broeg, K., Förlin, L., Gercken, J., Kopecka, J., Köhler, A., Parkkonen, J., Pempkowiak, J., Schiedek, D., 2006. Use of biliary PAH metabolites as a biomarker of pollution in fish from the Baltic Sea. Marine Pollution Bulletin (this volume).

Walker, C.H., 1995. Biochemical biomarkers in ecotoxicology - some recent developments. The Science of the Total Environment 171, 189195. 
WHO (World Health Organization), International Programme on Chemical Safety (IPCS), 1993. Biomarkers in risk assessment: concepts and principles. Environmental Health Criteria 155, Geneva, 80 p.

Whyte, J.J., Jung, R.E., Schmitt, C.J., Tillitt, D.E., 2000. Ethoxyresorufin$O$-deethylase (EROD) activity in fish as a biomarker of chemical exposure. Critical Reviews in Environmental Science and Technology 30 (4), 347-570.

Widdows, J., Donkin, P., 1992. Mussels and environmental contaminants: bioaccumulation and physiological aspects. In: Gosling, E. (Ed.), The
Mussel Mytilus: Ecology, Physiology, Genetics and Culture, Developments in Aquaculture and Fisheries Science, vol. 25. Elsevier, pp. 383-424.

Winston, G.W., Di Giulio, R.T., 1991. Prooxidant and antioxidant mechanisms in aquatic organisms. Aquatic Toxicology 19, 137-161.

Zebühr, Y., 1992. Trace Analysis of Polychlorinated Dibenzo-p-dioxins, Dibenzofurans and Related Compounds in Environmental Matrices. Ph.D. Thesis, Department of Analytical Chemistry, University of Stockholm, Sweden, p. 24, ISBN 91-87272-30-X. 